\title{
Conceptualization of flow and transport in a limestone aquifer by multiple dedicated hydraulic and tracer tests
}

Mosthaf, Klaus; Brauns, Bentje; Fjordbøge, Annika Sidelmann; Rohde, Magnus M.; Kerrn-Jespersen, Henriette; Bjerg, Poul Løgstrup; Binning, Philip John; Broholm, Mette Martina

Published in:

Journal of Hydrology

Link to article, DOI:

10.1016/j.jhydrol.2018.04.011

Publication date:

2018

Document Version

Peer reviewed version

Link back to DTU Orbit

Citation (APA):

Mosthaf, K., Brauns, B., Fjordbøge, A. S., Rohde, M. M., Kerrn-Jespersen, H., Bjerg, P. L., Binning, P. J., \& Broholm, M. M. (2018). Conceptualization of flow and transport in a limestone aquifer by multiple dedicated hydraulic and tracer tests. Journal of Hydrology, 561, 532-546. https://doi.org/10.1016/j.jhydrol.2018.04.011

\section{General rights}

Copyright and moral rights for the publications made accessible in the public portal are retained by the authors and/or other copyright owners and it is a condition of accessing publications that users recognise and abide by the legal requirements associated with these rights.

- Users may download and print one copy of any publication from the public portal for the purpose of private study or research.

- You may not further distribute the material or use it for any profit-making activity or commercial gain

- You may freely distribute the URL identifying the publication in the public portal 


\section{Accepted Manuscript}

Research papers

Conceptualization of flow and transport in a limestone aquifer by multiple dedicated hydraulic and tracer tests

Klaus Mosthaf, Bentje Brauns, Annika S. Fjordbøge, Magnus M. Rohde, Henriette Kerrn-Jespersen, Poul L. Bjerg, Philip J. Binning, Mette M. Broholm

PII: S0022-1694(18)30254-3

DOI: https://doi.org/10.1016/j.jhydrol.2018.04.011

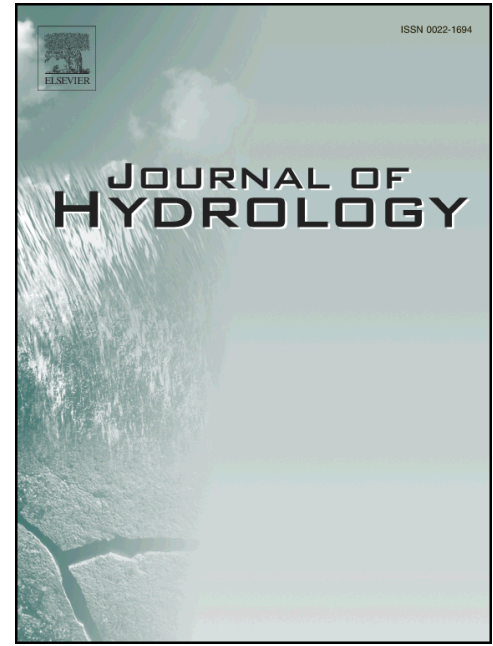

Reference:

HYDROL 22714

To appear in:

Journal of Hydrology

Received Date: $\quad 18$ September 2017

Revised Date: $\quad 28$ March 2018

Accepted Date: $\quad 3$ April 2018

Please cite this article as: Mosthaf, K., Brauns, B., Fjordbøge, A.S., Rohde, M.M., Kerrn-Jespersen, H., Bjerg, P.L., Binning, P.J., Broholm, M.M., Conceptualization of flow and transport in a limestone aquifer by multiple dedicated hydraulic and tracer tests, Journal of Hydrology (2018), doi: https://doi.org/10.1016/j.jhydrol.2018.04.011

This is a PDF file of an unedited manuscript that has been accepted for publication. As a service to our customers we are providing this early version of the manuscript. The manuscript will undergo copyediting, typesetting, and review of the resulting proof before it is published in its final form. Please note that during the production process errors may be discovered which could affect the content, and all legal disclaimers that apply to the journal pertain. 


\section{Conceptualization of flow and transport in a limestone aquifer by}

\section{multiple dedicated hydraulic and tracer tests}

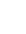

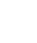

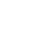

Klaus Mosthaf ${ }^{a} *$, Bentje Brauns ${ }^{\mathrm{a}}$, Annika S. Fjordbøge ${ }^{\mathrm{a}}$, Magnus M. Rohde Henriette Kerrn-Jespersen ${ }^{c}$, Poul L. Bjerg ${ }^{\mathrm{a}}$, Philip J. Binning ${ }^{\mathrm{a}}$, Mette M. Broholm ${ }^{\mathrm{a}}$

${ }^{a}$ DTU Environment, Technical University of Denmark, Bygningstorvet, 2800 Kgs. Lyngby, Denmark;

${ }^{\mathrm{b}}$ Geo, Maglebjergvej 1, 2800 Kgs. Lyngby, Denmark;

${ }^{c}$ Capital Region of Denmark, Kongens Vaenge 2, 3400 Hillerød, Denmark

0 Aquifer test, limestone, tracer test, hydrogeology, fractures, solute transport 


\section{Abstract}

Limestone aquifers are of great interest as a drinking water resource in many countries. They often have a complex crushed and fractured geology, which makes the analysis and description of flow and transport processes in such aquifers a challenging task. In this study, the solute transport behavior including fracture-matrix interaction in hydrogeological units of a limestone aquifer in eastern Denmark was characterized by designing, conducting and interpreting six depth-specific tracer tests involving natural- and forced-gradient conditions with multiple tracers representing different diffusion properties. To determine flow parameters, the tracer tests were complemented by a comprehensive set of depth-specific borehole and hydraulic tests.

Based on the tests, a new and stronger conceptual understanding was developed for the different aquifer units. The investigated limestone aquifer is composed of a glacially crushed unit and two fractured units, with calcarenitic and bryozoan limestone of similar hydraulic properties. Hydraulic tests revealed, that the crushed unit has a lower hydraulic conductivity than the fractured limestone units, likely due to the crushed conditions with small limestone clusters and small-aperture fractures potentially filled with fine material.

In the fractured limestone units, a distinct preferential flow and primary transport along major horizontal fractures was inferred from the tracer tests under forced-gradient conditions. The dominant horizontal fractures were identified on impeller flow logs and appear connected between wells, having an extent of up to several hundred meters. Connectivity between the aquifer units was investigated with a longterm pumping test and tracer tests, revealing restricted vertical flow and transport. A very pronounced hydraulic conductivity contrast between major fractures and matrix could also be inferred from the borehole and hydraulic tests, which is consistent with the findings from the tracer tests. However, the difference in the matrix diffusion behavior of the simultaneously injected tracers and a long tailing in the breakthrough curves revealed that matrix diffusion has a strong influence on the solute transport in the fractured limestone. 


\section{Introduction}

Limestone aquifers are important drinking water resources in many countries such as the UK, the USA and Niger (Ireson et al., 2009; Marella and Berndt, 2005; Qian et al., 2014). In Denmark, about one third of the water supply is based on groundwater from limestone aquifers (Vangkilde-Pedersen et al., 2011). Limestone aquifers in densely populated areas are vulnerable to contamination from diffuse and points sources due to heavy water abstraction, complex flow fields and low contaminant attenuation capacity (Aisopou et al., 2015; Levi et al., 2014). Therefore, knowledge on the hydrogeology and the flow and transport behavior in such aquifers is essential for groundwater resource management, risk assessment and remediation of contaminated sites. However, knowledge of transport in limestone aquifers is limited and difficult to acquire, particularly in fractured aquifers (Klepikova et al., 2014).

The flow field and the transport pathways in limestone aquifers can be very complex, as limestone is a very heterogeneous geological setting (Williams et al., 2006). Limestone often contains chert layers and nodules, may be weathered, crushed or fractured, and may contain fault zones due to geological activity (Jakobsen et al., 2017; Odling et al., 2013). In areas with glacial activity, the upper unit of the limestone often consists of distinct zones with different properties, e.g. reworked limestone mixed with till and sand, crushed or fractured limestone units (Jakobsen and Klitten, 1999), while deeper parts comprise intact geological units with a low fracture density (Jakobsen et al., 1993). Fractured units of limestone aquifers often exhibit a dual-continuum nature (Hartmann et al., 2007; Price et al., 1993): fast flow in a network of fractures dominates the advective transport in the aquifer, while the long-term fate of solutes is strongly influenced by matrix diffusion, sorption and degradation processes (Bottrell et al., 2010; Jardine et al., 1999; Witthuser et al., 2003).

Hydraulic characterization of limestone aquifers can include several traditional and more novel methods. Pumping tests and slug tests are commonly used for determining hydraulic conductivity and specific storage capacity values for all kinds of aquifers, including limestone aquifers (Ackerer and Delay, 2010; Butler et al., 2009; Kruseman and de Ridder, 1990; Macdonald and Allen, 2001). More recently, advanced characterization methods have been developed (Berkowitz, 2002; Neuman, 2005), including 
transmissivity profiling with FLUTe liners (Broholm et al., 2016; Keller, 2016), passive flux meters (Klammler et al., 2016), geophysical methods, optical and acoustical televiewer imaging (Maurice et al., 2012), impeller flow logging (Basiricò et al., 2015; Butler et al., 2009; Paillet, 1998), hydraulic tomography (Illman, 2013; Sanchez-León et al., 2015; Trottier et al., 2014), cross-borehole tests and thermal methods (Pehme et al., 2014; Somogyvári et al., 2016). However, some of the methods like FLUTe transmissivity profiling or optical televiewers require open boreholes. The borehole walls in fractured limestone and particularly in crushed limestone may be unstable and thus casings and well screens are installed to prevent borehole collapse (Odling et al., 2013). These installations restrict the choice of hydraulic and geologic characterization methods.

Tracer tests have been commonly used to determine parameters characterizing the transport behavior (porosity, matrix diffusion, dispersion) and connectivity in limestone aquifers (Bottrell et al., 2010; Hartmann et al., 2007) and other fractured aquifers. These tests can be performed as single-well or multiplewells tests, and with chemical species or heat as tracer (Doro et al., 2015; Somogyvári et al., 2016; Wagner et al., 2014). A single-well dilution test (Maurice et al., 2011; West and Odling, 2007) is a relatively simple and inexpensive method to identify high-flow zones within a borehole. Another kind of single-well test is a push-pull test (Becker and Shapiro, 2003), where the same well is used for tracer injection and extraction. Multiple-well tracer tests can be subdivided in natural-gradient (Bottrell et al., 2010; Jardine et al., 1999; LeBlanc et al., 1991; Ptak and Teutsch, 1994) and forced-gradient tracer tests (Hartmann et al., 2007; Jakobsen et al., 1993; Lloyd et al., 1996; Riley et al., 2001; Sanchez-León et al., 2015; Witthuser et al., 2003). Forced-gradient tracer tests establish a hydraulic gradient by pumping (and possibly by injecting), and have the advantage that the tracer breakthrough happens much faster than for natural gradient tracer tests. They also provide a well-defined flow field and tracer recovery is usually high. A well-defined flow field is particularly useful for fractured limestone aquifers, as it helps to reduce tracer loss and tracer occurrence at unexpected locations (Bottrell et al., 2010). A forced-gradient in a fractured medium caused by pumping may, however, activate additional flow paths compared to natural gradient conditions, as discussed by Butler et al. (2009). 
Only a few fully analyzed tracer tests in limestone aquifers have been reported in the literature. Amongst those, the tests of the eastern England Chalk are particularly notable (Black and Kipp, 1983; Bottrell et al., 2010; Hartmann et al., 2007; Maurice et al., 2012; Riley et al., 2001). Hartmann et al. (2007) performed a comprehensive forced-gradient tracer test study in a fractured limestone aquifer, using single fluorescent tracers for each injection. They mention the occurrence of a weathered, 'putty' chalk layer, in which the boreholes were cased. The injection and pumped intervals of the boreholes had a length of 46 to $55 \mathrm{~m}$, all in the fractured limestone aquifer, and different aquifer units were not distinguished. Bottrell et al. (2010) conducted lab and field tracer tests in a Chalk aquifer contaminated with hydrocarbons. The tracer tests were originally planned under forced-gradient conditions. However, the pumping rate could not be kept constant throughout the field experiment, hence the tracers were also monitored under natural gradient conditions after the initial pumping. Riley et al. (2001) present the results of an extensive tracer test study in Lincolnshire limestone using a borehole array for forced-gradient tracer tests with fluorescent and ionic tracers. They simultaneously applied multiple tracers and observed species-dependent tracer breakthrough behavior in lab column tests, but not when the tracer mixture was applied under field conditions. Jakobsen et al. (1993) present a forced-gradient tracer test applying lithium as tracer, while monitoring in five pumped intervals in a borehole located in the same unit of a fractured bryozoan limestone aquifer. They obtained tracer breakthrough curves showing fast tracer arrival and long tailings.

The results show that most of the presented tracer tests consider the limestone as a single aquifer unit. However, in many cases the upper limestone has different properties (Hartmann et al., 2007; Jakobsen and Klitten, 1999), for instance because of glacial activity, resulting in different flow and transport behavior. The upper limestone units are particularly important for contaminants infiltrating from diffuse or point sources, because their transport and fate will be highly depending on flow patterns and properties of these units. In most previous field studies in limestone, a single tracer was injected at the same time and location in limestone. However, the simultaneous injection of a mixture of tracers with different properties can provide additional information about the flow and transport processes in the aquifer, particularly about matrix diffusion, as reported in Jardine et al. (1999) for fractured shale bedrock and in Somogyvari and Bayer (2017) in the context of hydraulic tomography. 
The aim of this paper is to enhance the conceptual understanding of flow and solute transport in limestone aquifers with a focus on different aquifer units, involving crushed formations, fractures, and a low permeability matrix. This is an important step towards a better understanding of contaminant behavior, risk assessment and design of remedial actions in limestone aquifers. The site investigation techniques applied in this study involve a combination of tracer tests, borehole tests and hydraulic aquifer tests (pumping tests, slug tests etc.) to determine fracture-matrix interaction and matrix-diffusion behavior at the intermediate site scale (meters to a tens of meters). Two types of tracer tests were developed, where the first involved the simultaneous injection of multiple tracers with different diffusion coefficients in one borehole. The second involved injection of a tracer prior to pumping under natural-gradient conditions and subsequent monitoring at a pumping well under forced-gradient conditions. A novel feature of these hydraulic aquifer and tracer tests is that they were conducted in wells screened at different depths so as to obtain dedicated information about the main units in the upper weathered part of a limestone aquifer. The study was conducted in an aquifer consisting of an upper calcarenitic limestone and a lower bryozoan limestone at a field site situated in the eastern part of Zealand, Denmark (Figure 1a).

\section{Description of the field site}

A comprehensive field study was conducted in a limestone aquifer at the Akacievej site in Fløng, about $30 \mathrm{~km}$ west of Copenhagen (Figure 1a). The study of the site was motivated by the history and the current status as a contaminated site. The operation of a dry cleaning facility at the Akacievej site and a fire in 1975 had caused a spill of PCE and the development of a 400 to 500 meter long PCE plume in the limestone aquifer (Figure 1b), posing a risk to the groundwater resource. The site is not far from the abstraction wells of a local waterworks (Fløng), located ca. $700 \mathrm{~m}$ north of the Akacievej site, however with the current pumping rate the waterworks is not affected by the contamination. In 2006, the most contaminated soil (upper $6 \mathrm{~m}$ of the glacial deposits on top of the limestone aquifer) was removed and a pump-and-treat system was installed to establish hydraulic control of the contamination in the source zone and to limit further contaminant leaching and plume spreading. Aquifer water is continuously pumped at a 

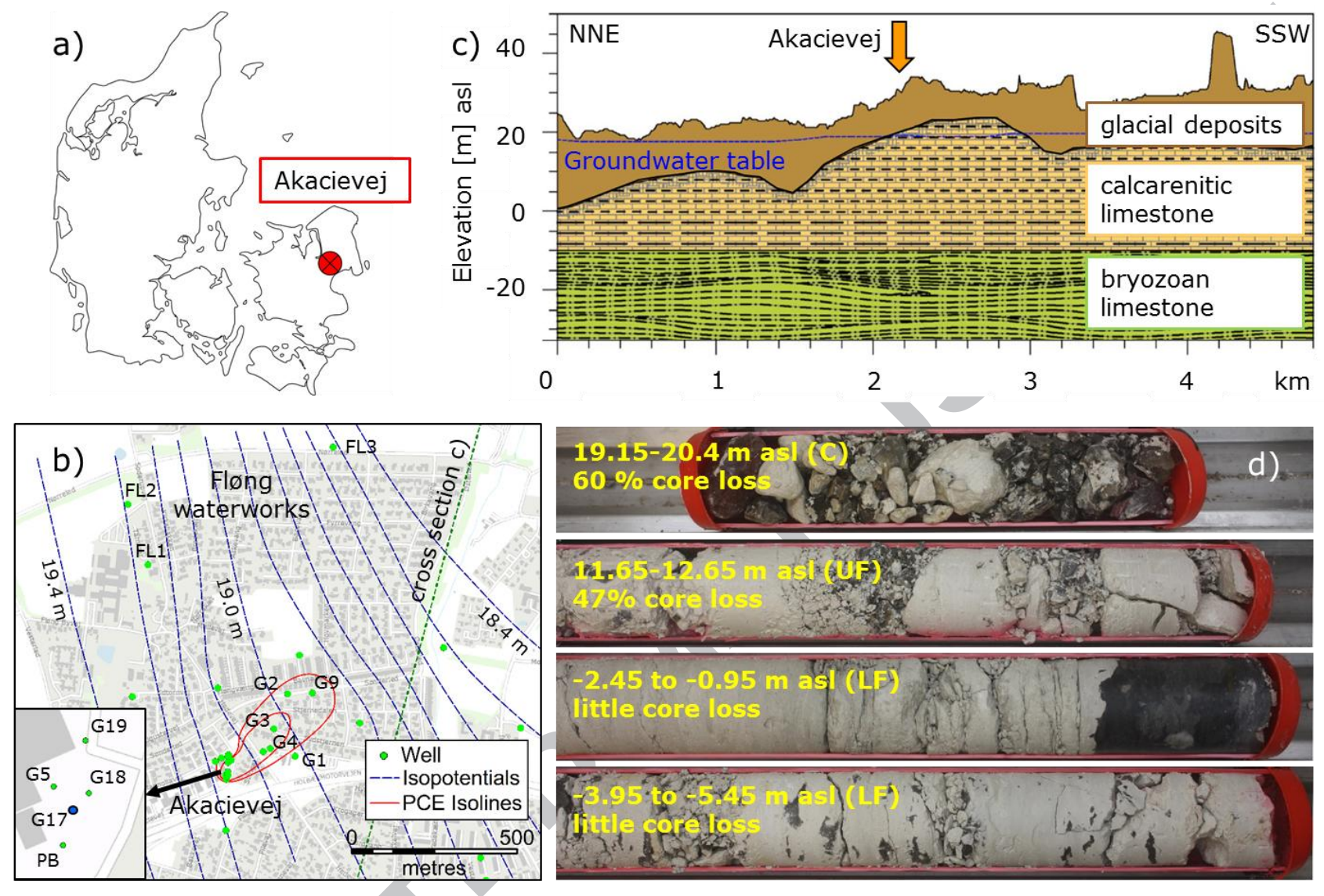

Figure 1: a) Map of Denmark showing the location of the field site. b) Site overview with isopotential lines in limestone without water abstraction at the Fløng waterworks and without remedial pumping, wells in the area and the approximate extent of the dissolved PCE plume in 2015. c) Regional geologic cross section showing the overarching stratigraphy with the geological understanding prior to this study (Galsgaard et al., 2014). d) Limestone borehole cores from different aquifer units at the site. From top to bottom: Crushed calcarenitic limestone, fractured calcarenitic limestone, upper fractured bryozoan limestone, lower fractured bryozoan limestone. Note that core losses in the crushed limestone were high and that most of the visible fractures in all units were created by the drilling.

\subsection{Geologic setting}

The general geology in the Fløng area was initially characterized using geologic and borehole data

161 from cores, borehole logs, outcrop analysis, geologic maps and microfossile analysis (Galsgaard et al., 2014;

162 Jakobsen et al. 2017), and a regional scale three-dimensional geologic model was established. This revealed

163 high spatial variability in the limestone aquifer and the fracture system, which highlights the need for

164 geologic characterization of local boreholes. Figure 1c) shows a geologic cross section with the typical 
A local geologic model was developed with information from new boreholes and measurements by different characterization methods from the field campaign in this study. The uppermost geologic layer consists of glacial deposits (clay- and sand till with a low permeability and sand inclusions) of a thickness of approximately 8-15 meters. The glacial deposits are underlain by two types of limestone of Danien age (Jakobsen et al., 2017), a calcarenitic limestone (Copenhagen limestone formation), and a bryozoan limestone (Stevns Klint formation). In contrast to the calcarenitic limestone, bryozoan limestone often shows bank structures (Jakobsen et al., 2017, 1993). Both the bryozoan limestone and the calcarenitic limestone contain chert layers and nodules and have a very variable hardness, spanning from soft limestone to cemented limestone and very hard chert. Figure 1d) shows limestone cores from different depths. The limestone aquifer is strongly affected by glacial activity. The upper 2 to 5 meters are crushed and the layers below are fractured. For the further analysis, the fractured limestone units were subdivided in an upper fractured (UF) unit containing the pumping test well screen, from the lower boundary of the crushed limestone at ca. $16 \mathrm{~m}$ asl down to $6 \mathrm{~m}$ asl, and a lower fractured (LF) unit down to the bottom of the hydraulically active limestone aquifer (Figure 2b). The calcarenitic limestone and the bryozoan limestone were not considered as different units in the following analysis, because the two limestone types did not show distinct differences in the hydraulic conductivity and porosity determined from the impeller flow logs and in the Poroperm tests (discussed in the results section).

\subsection{Hydrogeology} around the Akacievej site, and confined conditions are found at a distance of a few hundred meters (Figure 1c). The groundwater table shows seasonal variations with the highest levels in spring. In May 2015, it was at ca. $19 \mathrm{~m}$ asl, which is ca. $1.5 \mathrm{~m}$ below the top of the limestone aquifer at the Akacievej site. The regional groundwater flow field in the limestone aquifer was determined in a synchronous well sounding round (Figure 1b), for which the pump of the remediation system and the wells from the Fløng waterworks were switched off. The regional groundwater flow is directed towards east-north-east with an approximate hydraulic gradient of $0.8 \%$. The site is located in an area that is heavily used for drinking water abstraction 

influence the larger-scale groundwater flow field.

\section{Methods}

To conceptualize flow and solute transport in the three different limestone aquifer units at the site and to obtain detailed information on limestone matrix and fractures, six depth-specific tracer tests were combined with a long-term pumping test as described in the following. Complementary borehole and hydraulic aquifer tests were also carried out as described in the Supplementary Information (SI). Since the flow and transport properties in the fractured limestone unit were expected to change with depth, the fractured limestone unit was subdivided into an upper and a lower fractured limestone unit as shown in Figure 2b).
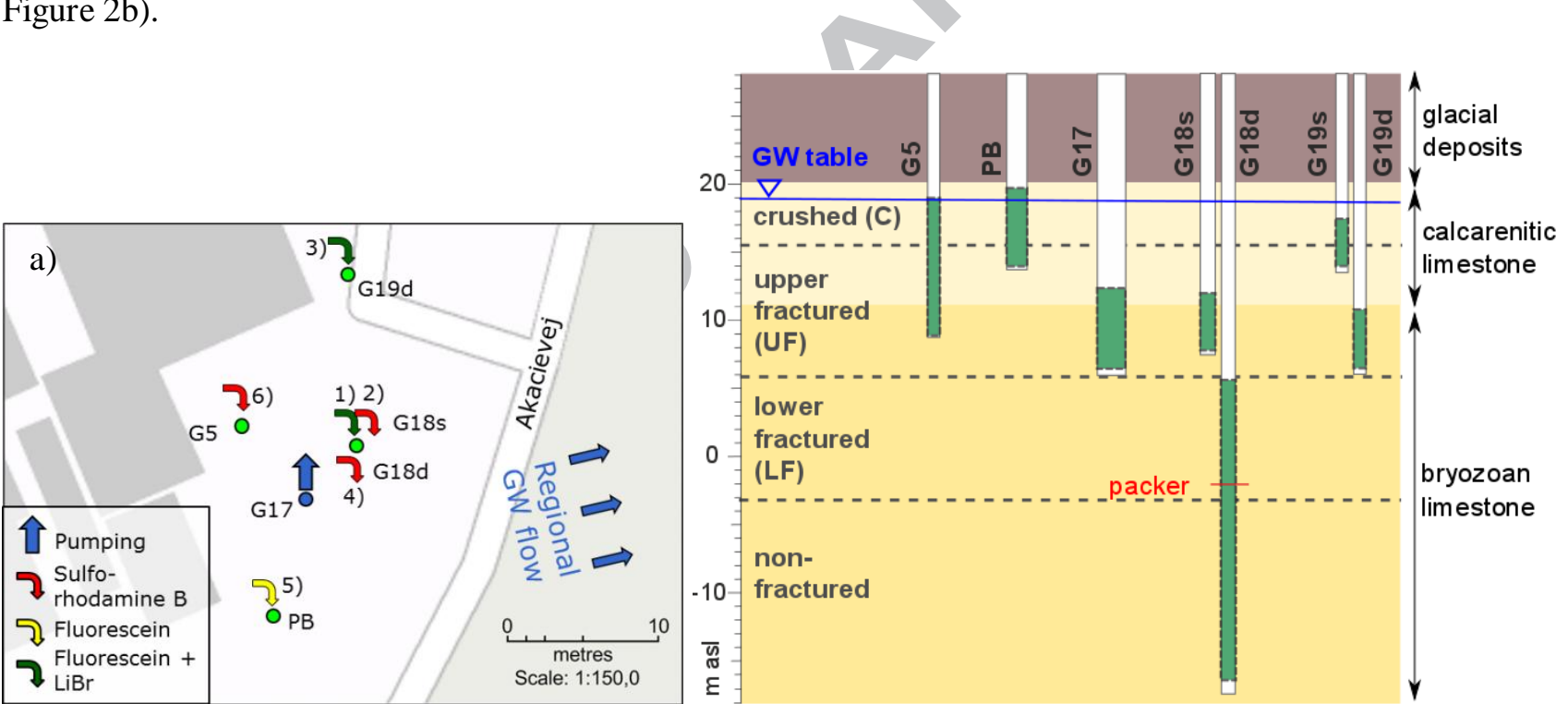

Figure 2a) Setup of the wells used for the pumping and tracer tests: Central pumping well (G17) with surrounding wells for tracer injections and hydraulic head monitoring. Employed tracers are indicated by the colored arrows, the regional groundwater flow (without pumping) is indicated by blue arrows. b) Vertical location of the well screens (green with dashed lines) in context with the limestone units and geologic limestone types. Stratigraphic/geological layers are indicated by colors (and double arrows on the right), while dashed black lines show the separation between units with different fracture properties.

\subsection{Boreholes and wells}

The limestone in the crushed and the upper fractured limestone unit was very unstable and it was not possible to construct open boreholes, thus preventing the planned usage of FLUTe transmissivity tests and other open-borehole tests. The lower fractured limestone was more stable and allowed for the deeper part of 
one borehole to be temporarily kept open. All other wells were completed as screened wells, with a 213 sand/gravel pack surrounding the screen.

Two wells from previous investigations (PB and G5, see Figure 2) were used for head monitoring and tracer injection. The well PB is the remediation well and is screened mainly in the crushed limestone. G5 was drilled with wire-line coring, cores were collected and a $10 \mathrm{~m}$ long screen was installed across both the upper fractured and the crushed limestone (Table 1 and Figure 2b).

The field investigation design included the construction of three new wells (G17-19) for pumping, 219 head monitoring and tracer injection. The wells were constructed with the down-the-hole (DTH) drilling 220 method. They were designed to give information about the different limestone units (crushed, upper 221 fractured and lower fractured unit). G17 was constructed as a central pumping well with a larger diameter and a $6 \mathrm{~m}$ long screen entirely in the upper fractured limestone (Table 1) to allow for specific tests in this aquifer unit and to test for the connectivity with the crushed and the lower fractured limestone units. G18 was constructed with a shallow screen (G18s) at the same depth as the pumping well screen, and a $22 \mathrm{~m}$ long deep screen (G18d) in the lower fractured limestone unit. Since G18d is located in the more stable part of the fractured limestone, it was initially created as an open borehole to conduct double-packer tests and optical televiewer logs for the characterization of the lower fractured limestone. After the tests, G18d was also screened. To investigate the properties of the upper two limestone units, G19 was constructed with two well screens: a shallow screen (G19s) mostly in the crushed limestone unit and a deep screen (G19d) in the upper fractured limestone unit. 
Table 1: Well properties and horizontal distances to pumping well (G17). The location of the main part of the well screen is assigned to the aquifer units: crushed (C), upper fractured (UF) and lower fractured (LF) limestone. The surface elevation at the Akacievej site is approximately $28.4 \mathrm{~m}$ asl. The three closest wells of the Fløng waterworks (FL1-3) are included, since they were used for wellshutdown tests, as explained in Supplementary Information (SI, 1.5).

\begin{tabular}{lllllll}
\hline Screen & $\begin{array}{l}\text { Horizontal } \\
\text { distance to G17 } \\
{[\mathrm{m}]}\end{array}$ & $\begin{array}{l}\text { Screen } \\
\text { length }[\mathrm{m}]\end{array}$ & $\begin{array}{l}\text { Screen depth } \\
{[\mathrm{m} \text { asl] }}\end{array}$ & Aquifer unit & $\begin{array}{l}\text { Casing diameter } \\
{[\mathrm{mm}]}\end{array}$ & $\begin{array}{l}\text { Borehole } \\
\text { diameter [mm] }\end{array}$ \\
\hline G17 & 0 & 6 & $6.4-12.4$ & UF & 225 & 345 \\
G18s & 5 & 5 & $7.5-12.5$ & UF & 110 & 345 \\
G18d & 5 & 22 & $-16.5-5.5$ & LF & 110 & 203 \\
G5 & 6.5 & 10 & $8.8-18.8$ & C/UF & 90 & 335 \\
PB & 8 & 6 & $13.9-19.9$ & C/UF & 165 & 345 \\
G19s & 15 & 3 & $14.3-17.3$ & C/UF & 90 & 203 \\
G19d & 15 & 4 & $6.3-10.3$ & UF & 90 & 300 \\
FL1 & 685 & 7 & $9-16$ & UF & 125 & 300 \\
FL2 & 877 & 12 & $1.1-13.1$ & UF/LF & 225 & 225 \\
FL3 & 1049 & 10 & $-11-(-1)$ & LF & & \\
\hline
\end{tabular}

\subsection{Pumping test design}

The long-term pumping test was designed to determine hydraulic dual-continuum parameters in the upper fractured limestone and to test the connectivity with tracer injection wells. The setup consisted of G17 as central pumping well surrounded by several monitoring wells (Figure 2). A Grundfoss SP 17-5 pump was employed and set to a constant pumping rate of $19.7 \mathrm{~m}^{3} / \mathrm{h}$ over two periods of about ten days each. A long duration and a relatively high pumping rate were chosen to obtain a drawdown curve which includes response from the matrix flow (Nielsen, 2007). The remediation system was turned off in the five months leading up to the pumping test.

Automatic pressure transducers (Schlumberger ${ }^{\circledR}$ Micro Divers) in the pumping well and six observation wells at distances between 5 and $50 \mathrm{~m}$ from the pumping well (Table 1) recorded the drawdown and recovery when the pump was switched on and off. A high measurement frequency $(2 \mathrm{~Hz})$ was applied to capture the first drawdown (water withdrawn mainly from fractures), which happened within few seconds. The collected long-term pressure data were corrected for barometric pressure variations and interpreted with specialized analytical solution methods for fractured media (Barker, 1988; Moench, 1984) and the software Aqtesolv (Duffield, 2007) to yield dual-continuum parameters for both fractures and matrix. 


\subsection{Tracer test design}

\subsubsection{Approach and design}

Six tracer tests were designed and carried out at the Akacievej site (Table 2), of which five tracer tests were conducted under forced-gradient conditions induced by the long-term pumping test, while one tracer test (G18s_pre) was initiated four days before start of the pumping test, so the tracer could spread with the natural groundwater flow and diffuse into the limestone matrix. Two of the six tests included the simultaneous injection of multiple tracers, whereas single tracers were applied in the other four tests.

Table 2: Overview of tracer tests with the respective injection well screen, used tracers and tracer amounts, and objectives of the tracer tests. The well screens are assigned to the aquifer units: crushed (C), upper fractured (UF) and lower fractured (LF) limestone. The tracers are sulforhodamine B (SRB), fluorescein (FL), lithium ( $\mathrm{Li})$ and bromide $(\mathrm{Br})$.

\begin{tabular}{|c|c|c|c|c|c|}
\hline $\begin{array}{l}\text { Injection well } \\
\text { screen }\end{array}$ & $\begin{array}{l}\text { Aquifer } \\
\text { unit }\end{array}$ & $\begin{array}{l}\text { Number of } \\
\text { tracers }\end{array}$ & Tracer(s) & $\begin{array}{l}\text { Tracer } \\
\text { amount }[\mathrm{g}]\end{array}$ & Objective/comment \\
\hline G18s_pre & UF & 3 & $\begin{array}{l}\mathrm{FL} \\
\mathrm{Br} \\
\mathrm{Li}\end{array}$ & $\begin{array}{l}4.34 \\
369.67 \\
32.11\end{array}$ & injection 4 days prior to pumping - diffusion into matrix \\
\hline G18s & UF & 1 & SRB & 2.99 & horizontal fracture transport properties \\
\hline G19d & UF & 3 & $\begin{array}{l}\mathrm{FL} \\
\mathrm{Br} \\
\mathrm{Li}\end{array}$ & $\begin{array}{l}20 \\
912.77 \\
79.29\end{array}$ & $\begin{array}{l}\text { horizontal transport properties with stronger influence of } \\
\text { matrix diffusion due to greater distance between injection } \\
\text { and extraction }\end{array}$ \\
\hline G5 & $\mathrm{C}+\mathrm{UF}$ & 1 & SRB & 2.5 & transport in $\mathrm{C}$ and $\mathrm{UF}$ from a different direction \\
\hline G18d & $\mathrm{LF}$ & 1 & & 9 & vertical transport, connectivity between LF and UF \\
\hline PB & $\mathrm{C}(+\mathrm{UF})$ & 1 & FL & 4.99 & vertical transport, connectivity between $\mathrm{C}$ and UF \\
\hline
\end{tabular}

The tracer injection wells were located at distances between 5 (G18) and $15 \mathrm{~m}$ (G19) from the pumping well (G17) with well screens in different aquifer units (Table 1). The distance between injection wells and the extraction well was kept short to reduce the required breakthrough time and to ensure a high tracer recovery to protect the downstream groundwater resource. More distant wells were excluded as possible injection locations because of the risk that the tracer could not be drawn to the pumping well. Figure 2 illustrates the setup and indicates the location of wells and screened intervals in context of the aquifer units.

Prior to the first tracer injection, aquifer water was abstracted at the site and stored in $1000 \mathrm{~L}$ tanks.

A concentrated tracer solution was mixed and transferred into the $1000 \mathrm{~L}$ tank immediately before the injection. When fluorescein and lithium bromide were simultaneously injected (G18s_pre, G19d), two separate concentrated tracer solutions were mixed into the same tank. The concentration of the tracer solution in the tank for the injection was chosen based on model simulations of the dilution of the tracer 
concentrations between injection and extraction well and on the quantification limits of the analytical

272 instruments. The tracer solution and the groundwater were thoroughly mixed in the tank for 30 minutes using 273 a recirculation pump and heated to the groundwater temperature of approximately $10^{\circ} \mathrm{C}$. The employed 274 tracer amounts and the objective of each test are shown in Table 2.

To ensure a uniform injection rate along the well screen, a special injection system was developed: 20 tubes with nozzles were fixed to a long PVC pipe and installed in the injection well.. The tracer solution was pumped from the tracer tank to the nozzles at the tube ends, which were placed to cover the entire well screen. The design of the tracer injection system is shown in Figure 3 and further described in the

Supplementary Information (SI, 2.2).

I1) Tracer tank

I2) Jet pump

I3) Flow distributor

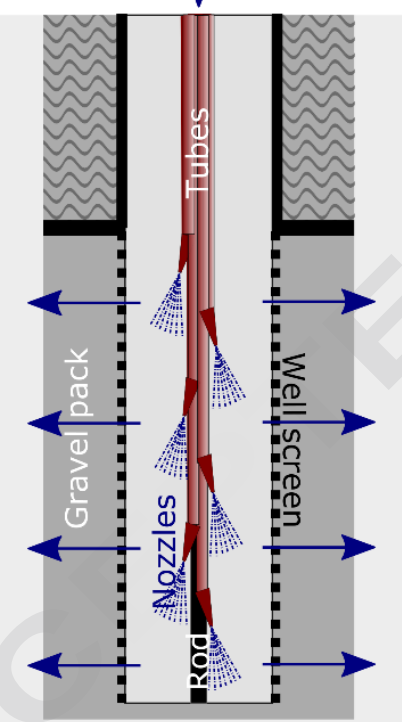

E1a) Flow-through Spectrophotometer

E1b) Sampling carousel (lab analysis)

E2) Activated carbon treatment

E3) Sewerage system

\section{Extraction (E)}

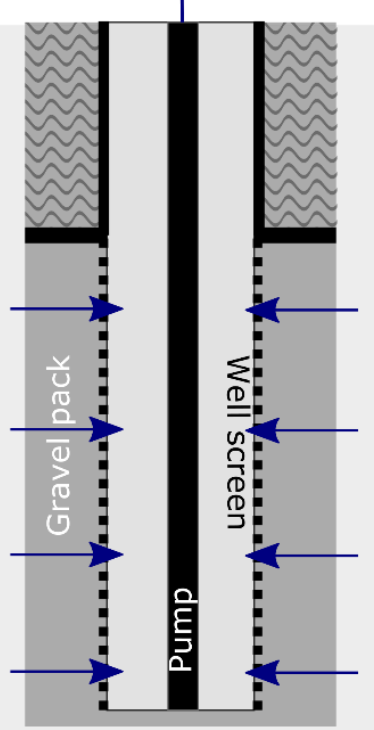

Figure 3: Setup of the specially developed tracer injection system (left) with nozzles fixed to injection tubes at constant depth intervals providing a uniform injection rate along the injection well screens. A jet pump delivers the tracer from a $1000 \mathrm{~L}$ tank to a flow distributor, which distributes the tracers through 20 tubes to the nozzles. Water with tracers was extracted through a pump (right). A small part of the water was diverted to a flow-through spectrophotometer and to a sampling carousel, while the major part was purified through activated carbon filters and released to the sewerage system.

The tracer injections were carried out as pulse injections of $1000 \mathrm{~L}$ tracer solution over approximately one hour, i.e. with a constant injection rate of $1000 \mathrm{~L} / \mathrm{h}$. After that, $200 \mathrm{~L}$ groundwater was injected as chaser to flush residual tracer out of the borehole and to clean the used equipment. Since an impeller flow log in G18d showed only negligible flow below $-7 \mathrm{~m}$, a tracer injection below this depth was 
prevented by the use of a packer sealing off the bottom part of the well (see Figure 2) during the tracer test in

291 G18d.

\subsubsection{Tracers}

Two fluorescent tracers with non-overlapping color spectra, namely disodium-fluorescein (uranine; referred to as fluorescein from hereon) and sulforhodamine B, and two ionic tracers, lithium and bromide, were selected and tested in the lab for their applicability and detectability. The tracers were chosen, because they are harmless to the aquifer, have a measurable contrast to background concentrations in the pristine groundwater and are easily detectable at low concentrations. Furthermore, some of the selected tracers had previously been successfully applied in limestone aquifers (Hartmann et al., 2007; Jakobsen et al., 1993; Riley et al., 2001). The sorption behavior of the fluorescent tracers was tested in short lab tests (see SI, 2.1), which indicated no (fluorescein) to very limited sorption (sulforhodamine B) to limestone and to the employed equipment material (tubes, vials). This is consistent with findings in Smart and Laidlaw (1977) who reported that sulforhodamine B and fluorescein have a moderate resistance to sorption in limestone. Bottrell et al. (2010) observed some sorption of fluorescein to limestone, but stated, that it proved to be an effective tracer in a tracer test over 300 days. Similarly, Riley et al. (2001) observed a weak sorption tendency of fluorescein in column experiments with Lincolnshire Limestone, but the sorption was insufficient to significantly affect the observed conservative behavior under field conditions. Bromide is known as a conservative, non-sorbing tracer.

Tracers with different molecular diffusion coefficients (see Table SI-1 for tracer properties) were chosen under the hypothesis that species with a higher diffusion coefficient would be more strongly affected by diffusion into the limestone matrix, thereby affecting downstream transport. Lithium is the smallest species but occurs mainly in a hydrated form (Cussler, 2011) and so bromide is the most strongly diffused tracer (Table SI-1) with the highest diffusion coefficient of the employed tracers. Single fluorescent tracers (either fluorescein or sulforhodamine B) were applied in four out of the six tracer tests, while in two tracer tests (G18s_pre and G19d), a mixture of fluorescein, lithium and bromide was injected to analyze the matrix diffusion behavior. 


\subsubsection{Sampling and monitoring}

The tracer concentrations were monitored in water diverted from the pumping well (G17) to a flowthrough spectrophotometer and a sampling carousel, which collected up to 24 water samples of about 120 $140 \mathrm{ml}$ each at predefined time intervals. The initial sampling frequency was chosen according to the anticipated breakthrough from numerical simulations and adjusted using the observed fluorescent tracer concentrations from the flow-through spectrophotometer. When the first tracer arrived at the pumping well, the tracer concentrations increased quickly and short sampling intervals down to 3 minutes were employed. After the initial tracer breakthrough, intervals were gradually increased to up to two hours. When lithium bromide was used as tracer, it was combined with fluorescein, and the fluorescein measurements with the flow-through spectrophotometer were used to decide the sampling frequency at the carousel. All samples were kept cool and dark until analyzed in the laboratory.

\subsubsection{Fluorescent tracers}

The fluorescent tracers were continuously monitored on-site with the fluorescence spectrophotometer (Varian Cary Eclipse) equipped with a flow-through cell. Additionally, unfiltered water samples from the sampling carousel were analyzed in the lab with a fluorescence spectrophotometer (Hitachi F7000). The lab measurements were considered to be more accurate and covered a larger range than the field measurements, because samples with concentrations above the measurement range could be diluted for the lab analysis. The best measurement wavelength for each tracer was tested beforehand (Table SI-1).

Analysis results showed that samples, which were originally filtered for the bromide analysis, gave more consistent results for fluorescein compared to noisy responses for the unfiltered samples. Probably, the fluorescein interacted with some dispersed particles in the groundwater during storage, leading to lower measured concentrations (dependent on the concentration of these particles in the respective sample). Hence, if available, the filtered samples were analyzed for their fluorescein concentrations.

\subsubsection{2. $\quad$ Ionic tracers}

Bromide was analyzed by ion chromatography (see SI, 2.3). The lithium concentrations were analyzed by an accredited laboratory (Eurofins Miljoe A/S Laboratories), using an Agilent ICP-MS. 


\subsubsection{Sequence of tracer tests}

The tracer tests were carried out over a period of five weeks (Figure 4). The first tracer test (G18s_pre) was initiated four days before the pumping test was started, simultaneously injecting fluorescein and lithium bromide. Two days after the pump start the second tracer test was carried out in G18s with sulforhodamine B. The second tracer test was started when the measured tracer concentrations from the first test had returned to levels close to the background concentrations and to the detection limits for the fluorescein. However, the analysis of the water samples in the lab showed that the breakthrough from the first tracer test was not completely over when the second tracer test was started, and the injection of the second tracer solution caused a dilution of the tracers from the first tracer test (described in the results section, see Figure 8c). Further, the forced hydraulic gradient induced by the pumping was likely to have activated some new flow pathways compared to the natural-gradient flow conditions, as also observed in a field study by Butler et al. (2009).

The third and fourth tracer test were performed in G18d and G19d on the same day, four days after the injection of the second tracer test (G18s). This was possible, because two different fluorescent tracers were used and the tracers were injected in wells on opposite sides of the extraction well (G17, Figure 2), which was pumping at a high rate. Hence, a mutual influence of the two tracer tests could be excluded. The same applies for the last two tracer tests in G5 and PB, which were carried out on the same day, two and a half weeks after the injection of the third and fourth tracer test (G18d and G19d).

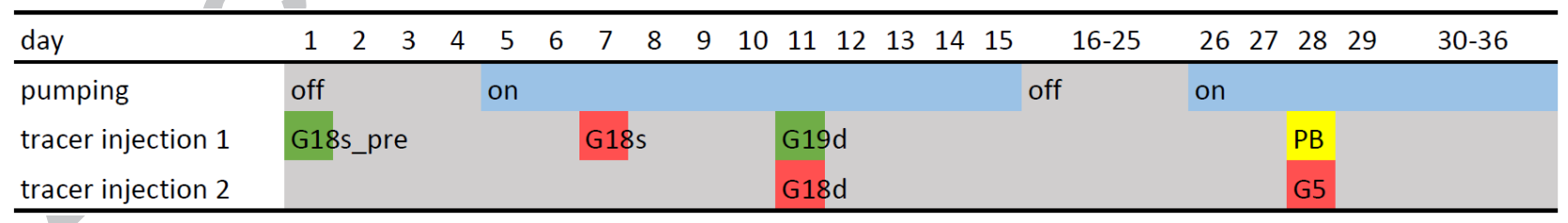

Figure 4: Timeline for pumping and tracer tests. The used tracers are indicated by the color. Red: Sulforhodamine B, yellow: fluorescein, green: fluorescein + lithium bromide.

\subsection{Complementary aquifer tests}

Complementary aquifer tests included borehole core analysis, geophysical borehole logs, doublepacker tests and vacuum slug tests, and are further described in Supplementary Information (SI, 1.1-1.5). The most important ones are listed in the following: Drawdown and recovery data from shutting down and 
reactivating the wells of the pump-and-treat system and the Fløng waterworks were evaluated to obtain a first approximation of the average hydraulic conductivity in the aquifer. Slug tests yielded further hydraulic conductivity values at specific depths and locations. The analysis of small limestone matrix cores in Poroperm tests yielded matrix porosity and hydraulic conductivity values of the limestone of different hardness from each limestone unit. Highly conductive zones were detected by Impeller flow logs.

\subsection{Data treatment and calculations}

The tracer recovery $\mathrm{R}$ was calculated as

$$
R=\sum_{i}\left(c_{i}-c_{b g}\right) \cdot Q \cdot \Delta t_{i} / M_{i n j}
$$

with the time interval $i$, the measured concentration $c_{i}$, the background concentration $c_{b g}$ (only for bromide and lithium), the constant pumping rate $Q\left(19.7 \mathrm{~m}^{3} / \mathrm{h}\right)$ and the injected tracer mass $M_{i n j}$. The fluorescence spectrophotometers were calibrated with the groundwater from the site, hence it was not necessary to correct the fluorescein and sulforhodamine B measurements for background fluorescence.

The temporal moment analysis provides a quantitative description of the characteristics of the tracer breakthrough curves and to allow for a comparison between the different tracer tests. The temporal moments were calculated as (Cirpka and Kitanidis, 2000; Govindaraju and Das, 2007):

- absolute time moment: $\mu_{n}=\int_{0}^{\infty} t^{n} c(x, t) d t$

- normalized absolute moment: $\mu_{n}^{*}=\frac{\mu_{n}}{\mu_{0}}$

The second and third central moment characterize the spreading and skewness of the breakthrough curve and were calculated as (Sánchez-Vila and Carrera, 2004):

- $\quad$ second central normalized moment: $m_{2}=\mu_{2}^{*}-\mu_{1}^{* 2}$

- $\quad$ third central normalized moment: $m_{3}=\mu_{3}^{*}-3 \mu_{2}^{*} \mu_{1}^{*}+2 \mu_{1}^{*}$ 


\section{Results and discussion}

389 4.1. Hydraulic properties of aquifer units from pumping and aquifer tests

\subsubsection{Hydraulic conductivity}

The hydraulic conductivity values of the aquifer units (Figure 2) obtained with different aquifer tests are summarized in Table 3, showing a strong contrast between fracture and matrix conductivity and a lower conductivity in the crushed than in the fractured limestone units.

Table 3: Hydraulic conductivity values in $\mathrm{m} / \mathrm{s}$ determined by aquifer tests in the aquifer units $(\mathrm{C}=$ crushed, $\mathrm{UF}=$ upper fractured, $\mathrm{LF}=$ lower fractured), see Figure 2. The crushed material was evaluated as a single-porosity medium with one hydraulic conductivity, which is lower than in the fractured units. The long-term pumping test yielded dual-continuum parameters in the fractured limestone units. The slug tests mainly provided the fracture conductivity, while the Poroperm tests determined the matrix porosity and conductivity.

\begin{tabular}{|c|c|c|c|c|c|c|c|}
\hline & Hydraulic test & $\mathrm{n}$ & Wells & \multicolumn{3}{|c|}{ Hydraulic conductivity [m/s] } & \multirow[t]{2}{*}{ Annotations } \\
\hline & & & & $\min$ & $\operatorname{Max}$ & avg & \\
\hline \multirow[t]{2}{*}{ Crushed } & pumping test $^{\mathrm{a}}$ & 1 & PB & & 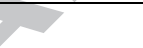 & $2.50 \times 10^{-4}$ & remediation well \\
\hline & slug test & 1 & G19s & $2.36 \times 10^{-4}$ & $3.60 \times 10^{-4}$ & $2.87 \times 10^{-4}$ & 10 repetitions \\
\hline \multirow[t]{3}{*}{$\begin{array}{l}\text { UF - } \\
\text { fractures }\end{array}$} & pumping test & 1 & $\begin{array}{l}\text { G17 + obs. } \\
\text { Wells }\end{array}$ & $1.27 \times 10^{-3}$ & $5.31 \times 10^{-3}$ & $2.04 \times 10^{-3}$ & long-term test \\
\hline & pumping test $^{\mathrm{b}}$ & 2 & FL1, FL2 & $4.44 \times 10^{-5}$ & $4.17 \times 10^{-4}$ & $2.31 \times 10^{-4}$ & Fløng waterworks \\
\hline & slug test & 1 & G19 & $1.90 \times 10^{-3}$ & $2.12 \times 10^{-3}$ & $2.03 \times 10^{-3}$ & 5 repetitions \\
\hline \multirow[t]{3}{*}{ UF - matrix } & pumping test & 1 & $\mathrm{G} 17$ + obs. & $5.15 \times 10^{-10}$ & $5.91 \times 10^{-7}$ & $1.97 \times 10^{-7}$ & long-term test \\
\hline & pumping test ${ }^{\mathrm{b}}$ & 2 & FL1, FL2 & $1.88 \times 10^{-8}$ & $2.52 \times 10^{-8}$ & $2.20 \times 10^{-8}$ & Fløng waterworks \\
\hline & Poroperm $^{c}$ & 4 & G5, G4, G9 & $5.21 \times 10^{-11}$ & $1.05 \times 10^{-6}$ & $1.93 \times 10^{-7}$ & 11 subcores \\
\hline \multirow{3}{*}{$\begin{array}{l}\text { LF - } \\
\text { fractures }\end{array}$} & pumping test & 1 & $\mathrm{G} 17$ (G18d) & $2.55 \times 10^{-3}$ & $1.14 \times 10^{-2}$ & $6.52 \times 10^{-3}$ & evaluated at G18d \\
\hline & pumping test ${ }^{\mathrm{d}}$ & 4 & G18d & $2.61 \times 10^{-4}$ & $3.47 \times 10^{-2}$ & $1.62 \times 10^{-2}$ & 4 packer tests \\
\hline & pumping test ${ }^{\mathrm{b}}$ & 2 & FL2, FL3 & $9.45 \times 10^{-5}$ & $4.17 \times 10^{-4}$ & $2.56 \times 10^{-4}$ & Fløng waterworks \\
\hline \multirow[t]{3}{*}{ LF - matrix } & pumping test & 1 & G17 (G18d) & $1.32 \times 10^{-6}$ & $2.10 \times 10^{-6}$ & $1.71 \times 10^{-6}$ & evaluated at $\mathrm{G} 18 \mathrm{~d}$ \\
\hline & pumping test $^{\mathrm{b}}$ & 2 & FL2, FL3 & $1.78 \times 10^{-8}$ & $1.88 \times 10^{-8}$ & $1.83 \times 10^{-8}$ & Fløng waterworks \\
\hline & Poroperm ${ }^{c}$ & 11 & G5, G4, G9 & $5.21 \times 10^{-11}$ & $1.05 \times 10^{-6}$ & $1.93 \times 10^{-7}$ & 11 subcores \\
\hline
\end{tabular}

${ }^{\mathrm{a}}$ evaluation of shutdown and reactivation of remediation system

${ }^{\mathrm{b}}$ pump shutdown and reactivation test at abstraction wells at the Fløng waterworks (FL1 - FL3), ca. $700 \mathrm{~m}$ from the Akacievej site

${ }^{\mathrm{c}}$ hardness H2 (2 subcores): $1 \times 10^{-6} \mathrm{~m} / \mathrm{s}$, porosity of 45.2-46.1 \%, hardness H3 (1 subcore): $2.7 \times 10^{-8} \mathrm{~m} / \mathrm{s}$, porosity of $28.4 \%$, hardness H4 (9 subcores): $0.1-7 \times 10^{-9} \mathrm{~m} / \mathrm{s}$, porosity of 7.2-15.9\%. Values are considered as representative for both UF and LF limestone matrix

$404{ }^{\mathrm{d}}$ packer tests in G18d, focused on high-conductive zones 
The long-term pumping test was conducted with a pumping rate of $19.7 \mathrm{~m}^{3} / \mathrm{h}$ in $\mathrm{G} 17$, which was screened in the upper fractured limestone unit, and yielded a dual-continuum fracture conductivity of ca. $2 \times 10^{-3} \mathrm{~m} / \mathrm{s}$ at the pumping well. The high conductivity was reflected in an abrupt initial drawdown of $25 \mathrm{~cm}$ in the pumping well and in the maximum drawdown of ca. $31 \mathrm{~cm}$ (Figure 5). Connectivity provided by fractures between the wells was evident in the distinct and very fast hydraulic head response within few seconds in all observation wells (Figure 5). The fracture conductivity of the upper limestone was high 411 compared to that seen in other limestone aquifers where conductivities range between $10^{-5}$ to $10^{-3} \mathrm{~m} / \mathrm{s}$ 412 (Downing et al., 1993; Hartmann et al., 2007; Jakobsen et al., 1993).

Hydraulic conductivities of the matrix were determined by Poroperm tests, which yielded detailed hydraulic conductivity values for samples on the scale of centimeters. These tests showed that the matrix conductivity is three to eight orders of magnitude lower than the fracture conductivities determined by the pumping tests. Negligible differences between the calcarenitic and the bryozoan limestone of the same hardness were observed, hence they were treated as one aquifer unit (see Figure 2). The pumping tests 418 yielded matrix conductivities, which lie within the range determined by the Poroperm tests, however, the 419 range determined by the pumping tests was much narrower. This was thought to be because the Poroperm tests are small-scale tests while pumping tests determine average hydraulic conductivity values for a large aquifer volume (tens of meters). Hence, the Poroperm tests provide a good indication of the heterogeneity of the limestone matrix. Due to the observed strong conductivity contrast between fractures and matrix, advective flow mainly occurs in the fractures and the flow in the matrix is very slow and negligible. 

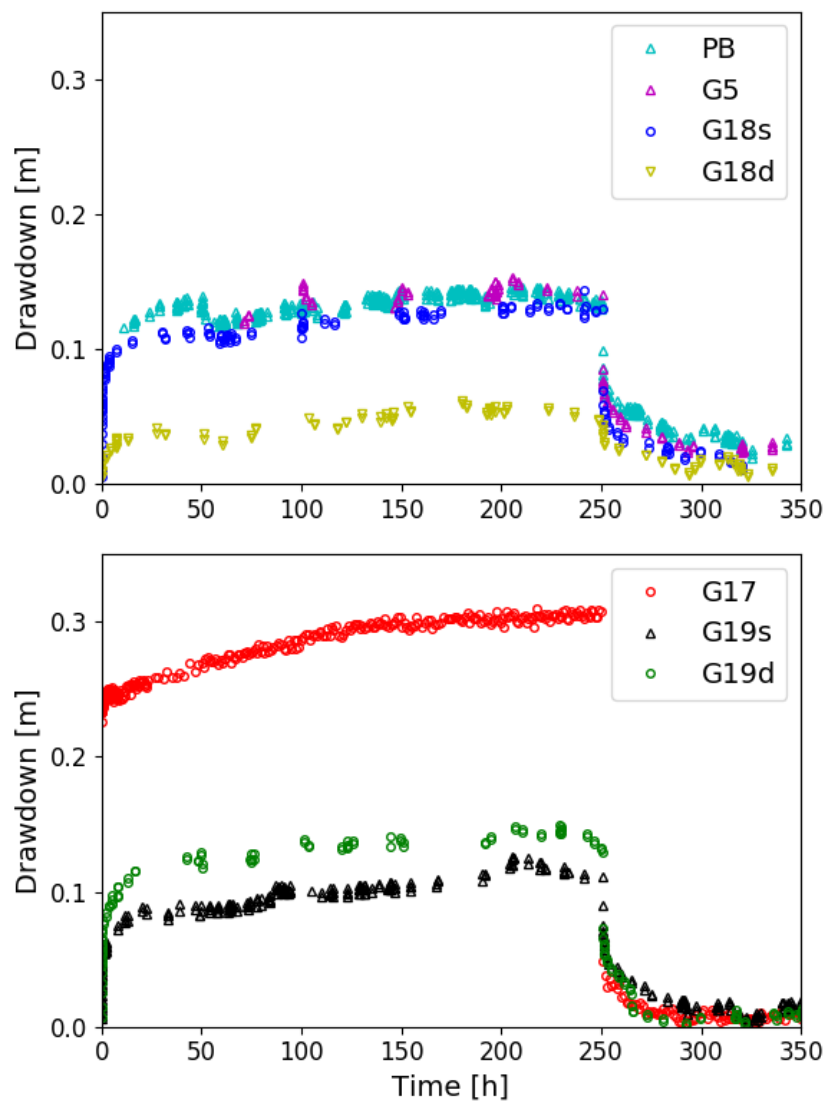

Figure 5: Drawdown at wells during the long-term pumping test in G17 (upper fractured unit). The initial drawdown happened quickly and the drawdown could be observed in all observation wells. PB, G5, G18s and G19d showed a similar drawdown. G18d (lower fractured unit) had the smallest drawdown and the drawdown in G19s (crushed - upper fractured unit) was slightly smaller than in G19d. After 251 hours, the pump was switched off.

With about $2.5 \times 10^{-4} \mathrm{~m} / \mathrm{s}$, the hydraulic conductivity determined in the crushed limestone (G19s) was about one order of magnitude lower than that of the upper fractured limestone unit. An explanation could be that the crushed limestone unit has smaller fractures and less pronounced flow zones than the fractured units. Moreover, fine material (e.g. glacial deposits) may be mixed into the crushed limestone, filling fractures and major flow paths as indicated by borehole log descriptions.

The small drawdown in the lower fractured limestone unit (G18d) and in the wells screened in the crushed limestone unit (PB, G19s) caused by the pumping test indicates that these aquifer units are, albeit to a limited extent, hydraulically connected to the upper fractured limestone. The evaluation of the drawdown data at G18d and the double-packer tests revealed a slightly higher horizontal hydraulic conductivity in the lower than in the upper fractured limestone unit. The double-packer tests were, however, focused on the 
highly conductive zones in the lower fractured limestone. Hence, the higher conductivity value determined with the packer tests is not surprising.

The hydraulic conductivities inferred from the vacuum slug tests in G19s and G19d were in the same range as the values from the evaluation of the drawdown caused by the remediation system and the values determined for the fracture system by the long-term pumping test. This differs from the obseryations in Butler and Healey (1998), who discussed often-observed higher hydraulic conductivities determined by pumping tests than determined by slug tests within the same borehole in non-fractured geologies. They relate these differences mainly to incomplete well development and disturbances caused by the well construction

like drilling debris. The good match between pumping test and slug test results in this study suggests a negligible influence of the well construction on the major flow paths (fractures) in the vicinity of G19s and G19d.

Compared to pumping tests, slug tests are more local measurements, since the release of the water slug only affects a small volume of water (mainly in the major fractures with a high conductivity) in the fractured limestone aquifer with a high hydraulic conductivity. aquifer volume immediately surrounding of the tested well. Slug tests have the advantage of being much quicker and cheaper than pumping tests to conduct. Hence, a series of slug tests in several wells (if present) can be conducted to cover a larger area, giving also information about the spatial variability of the hydraulic conductivity. Moreover, slug tests have a smaller effect on the local distribution of contaminants compared to pumping tests, which require a high pumping rate to induce a distinct drawdown in a larger area of a

However, slug tests as sole method to determine hydraulic parameters may fail to capture hydraulic features at a larger scale relevant for contaminant migration. The values determined by slug tests are more dependent on the horizontal and vertical location of the well and the conditions of the well. Because of this, pumping tests are also important for contaminated site investigations and can be complementary to the slug tests. They are particularly useful in combination with forced-gradient tracer tests to determine both, flow and transport parameters.

The evaluation of the drawdown at the three wells of the Fløng waterworks, screened at different depths, yielded conductivity values about one order of magnitude lower than the ones determined in the 
fractured limestone by the long-term pumping test. This is not surprising recalling that the boreholes are placed $700 \mathrm{~m}$ apart. In this study, the main value of the hydraulic conductivity obtained from shutdown of the abstraction wells were for planning of field activities and installations. It is recommended to consider use of existing pumping systems for this purpose and for upscaling of data to larger areas. The use of existing pumping systems provides an economic and simple way for determining aquifer data, without the need to drill new boreholes and with little additional disturbance of the aquifer. A similar approach has been proposed by Tiedeman et al. (2010), who used an on-going pump and treat system for obtaining hydraulic properties of a fractured rock aquifer.

\subsubsection{Fracture characterization}

The long-term pumping test yielded dual-continuum parameters for the fracture system and the matrix, particularly in the upper fractured limestone unit, where the pumping well G17 is screened. When aquifer test analyses provide an averaged hydraulic conductivity for a single continuum (slug test evaluations), the determined values mainly represent the fracture conductivity because of the large contrast between fracture and matrix conductivity.

Hydraulically active fractures and major flow zones were revealed by impeller flow logs at the tested wells, as described in Molz et al. (1989). An example flow log showing a major horizontal fracture is shown in Figure 6. The flow zones detected on the flow logs appeared to be relatively horizontal and parallel, and were interpreted to extend between the tested wells, consistent with the connectivity observed in the longterm pumping test. The interpretation of impeller flow logs in wells at and around the Akacievej site suggested that some fractures had a horizontal extent of several hundred meters. The larger aperture fractures could also be observed on the caliper log. It could be concluded that the most conductive fractures had a hydraulic aperture of $1-3 \mathrm{~mm}$. Chert, either occurring as layers or as nodules, was identified on borehole logs, in borehole cores, and on the optical televiewer log in G18d in the lower fractured limestone (dark grey areas are chert, the fracture is black, Figure 6). 


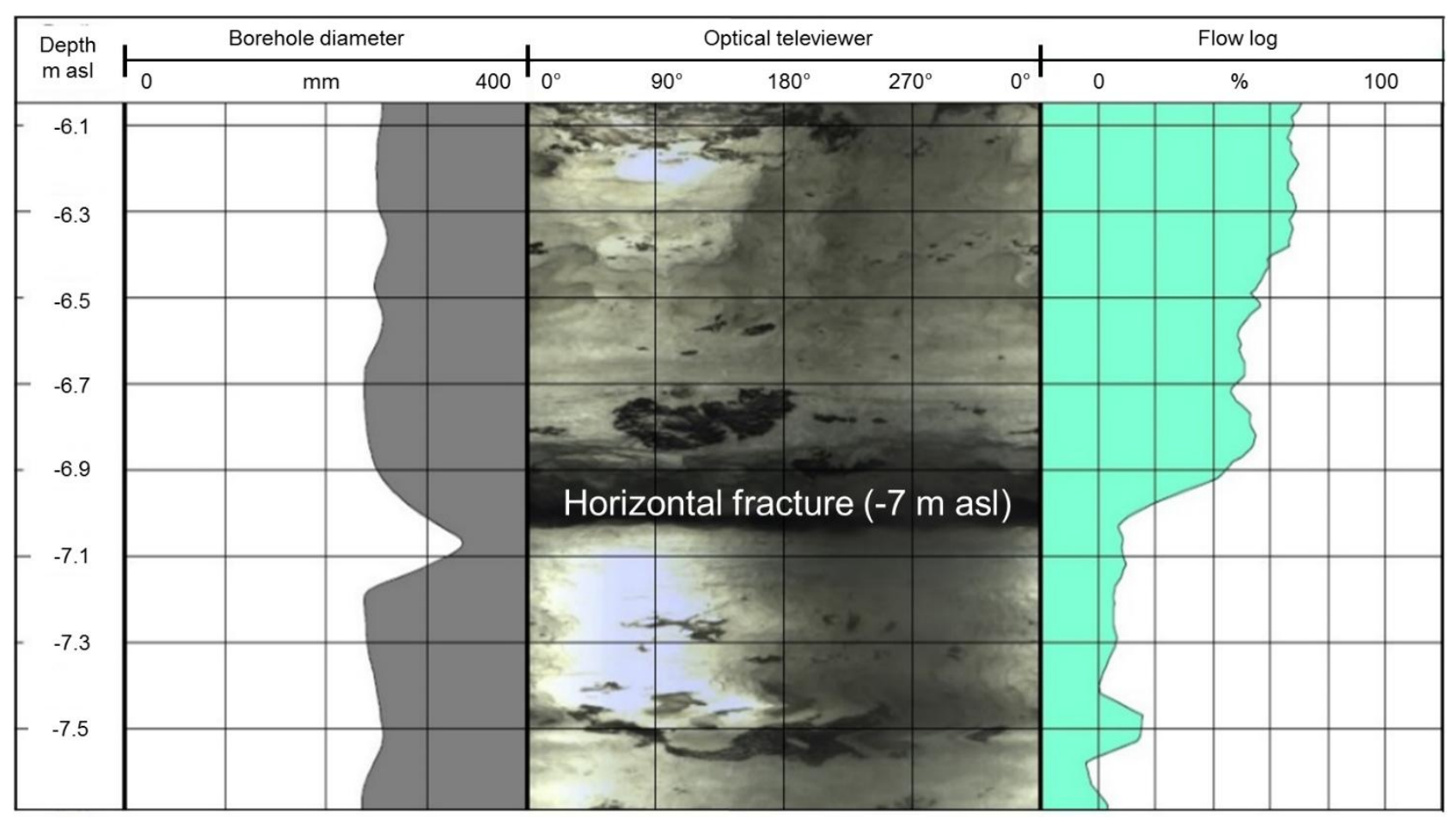

Figure 6: Optical televiewer image showing a section of the borehole wall in G18d (-6.1 to $-7.7 \mathrm{~m}$ asl). The black part at $-7.0 \mathrm{~m}$ asl indicates a major horizontal fracture, chert is dark grey. The fracture is reflected in the caliper measurements (left) and the flow log (right), which shows a strong inflow to the well.

A single subvertical fracture (joint) with a small aperture intersected G18d and was identified at ca. $-1.5 \mathrm{~m}$ asl on the optical televiewer image. It had a length of approximately $40 \mathrm{~cm}$ and connected two horizontal fractures. Ten subvertical fractures were observed on the cores from G5 and two wells in the downstream plume area (G4, G9, Figure 1b), with fracture lengths between 9 and $50 \mathrm{~cm}$. Precipitates were found on the surface of three of them, indicating that they were hydraulically active fractures and not created during drilling and sampling of the core. The dominant orientation of the subvertical fractures was assumed to follow the orientation of know faults in the area surrounding the site (N-S/NNW-SSE, see Jakobsen et al. (2017)). The horizontal spacing between subvertical fractures was estimated based on the core analyses to be between 1.3 and $2.5 \mathrm{~m}$. However, the distance between hydraulically active fractures was estimated to be up to $5 \mathrm{~m}$ based on the fractures containing precipitates.

The double-packer tests in sections of the open part of G18d allowed for the calculation of hydraulic apertures for the tested aquifer sections in the lower fractured limestone (Table 4). Surprisingly, horizontal fractures with apertures of up to $3 \mathrm{~mm}$ could be observed down to a depth of $-7 \mathrm{~m}$ asl, showing a rather uniform fracture distribution above this depth. This observation was contrary to the expectation of fracture 
density and aperture decreasing with depth by (Downing et al., 1993; Hartmann et al., 2007; Jakobsen et al., 1993), and of flow and transport predominantly occurring in the upper fractured limestone. Hence, the results reveal a potential for significant flow and transport in high conductivity fractures even in the deeper aquifer unit and illustrates the diversity of fractured limestone aquifers.

Table 4: Depth of horizontal fractures identified on the optical televiewer image and the flow log in G18d. Transmissivity values and hydraulic conductivities were determined based on four double-packer tests on $1.5 \mathrm{~m}$ intervals. Hydraulic apertures were calculated based on the cubic law. The first four fractures were in the same depth interval, and a hydraulic aperture assuming one fracture in the 515 interval and assuming four fractures with the same apertures are listed.

\begin{tabular}{llllll}
\hline $\begin{array}{l}\text { Interval } \\
\text { no. }\end{array}$ & $\begin{array}{l}\text { Depth interval (packer) } \\
{[\mathrm{m}] \text { asl }}\end{array}$ & $\begin{array}{l}\text { Interval } \\
\text { transmissivity } \\
{\left[\mathrm{m}^{2} / \mathrm{s}\right]}\end{array}$ & $\begin{array}{l}\text { Hydraulic } \\
\text { conductivity } \\
{[\mathrm{m} / \mathrm{s}]}\end{array}$ & $\begin{array}{l}\text { Fracture } \\
\text { location } \\
{[\mathrm{m}] \text { asl }}\end{array}$ & Hydraulic aperture 2b [mm] \\
\hline 1 & -0.28 to -1.78 & $5.20 \times 10^{-2}$ & $3.47 \times 10^{-2}$ & -0.63 & $4.36(1$ large fracture) \\
& & & & -0.83 & 2.74 (4 equal fractures) \\
& & & -1.33 & \\
& & & & -1.73 & \\
2 & -3.03 to -4.18 & $2.20 \times 10^{-2}$ & $1.47 \times 10^{-2}$ & -3.03 & 3.27 \\
3 & -4.78 to -6.28 & $3.00 \times 10^{-4}$ & $2.61 \times 10^{-4}$ & -5.83 & 0.78 \\
4 (Fig. 5) & -6.28 to -7.78 & $2.30 \times 10^{-2}$ & $1.53 \times 10^{-2}$ & -7.03 & 3.32 \\
\hline
\end{tabular}

\subsubsection{Matrix properties}

The matrix hydraulic conductivities determined in Poroperm tests on matrix cores with a hardness H2-H4 (Larsen et al., 1995) are low (Table 3), and span over a wide range $\left(5 \times 10^{-11}\right.$ to $\left.10^{-6} \mathrm{~m} / \mathrm{s}\right)$. The matrix porosity varied between 7 and $46 \%$ with an average of $19 \%$, showing a strong variability with depth. The hydraulic conductivity and porosity ranges are larger than reported in Jakobsen et al. (1993) for a similar site. The hydraulic conductivity and the porosity were correlated and both could be related to the hardness of the limestone cores (Figure 7), which was registered in drilling logs. Borehole cores with a lower hardness were rather grainy, in general more conductive, and had a higher porosity when compared to the more cemented cores with a high hardness. Impermeable chert with the highest hardness (H5) was found in all aquifer units, either as connected layers or as nodules / inclusions. 

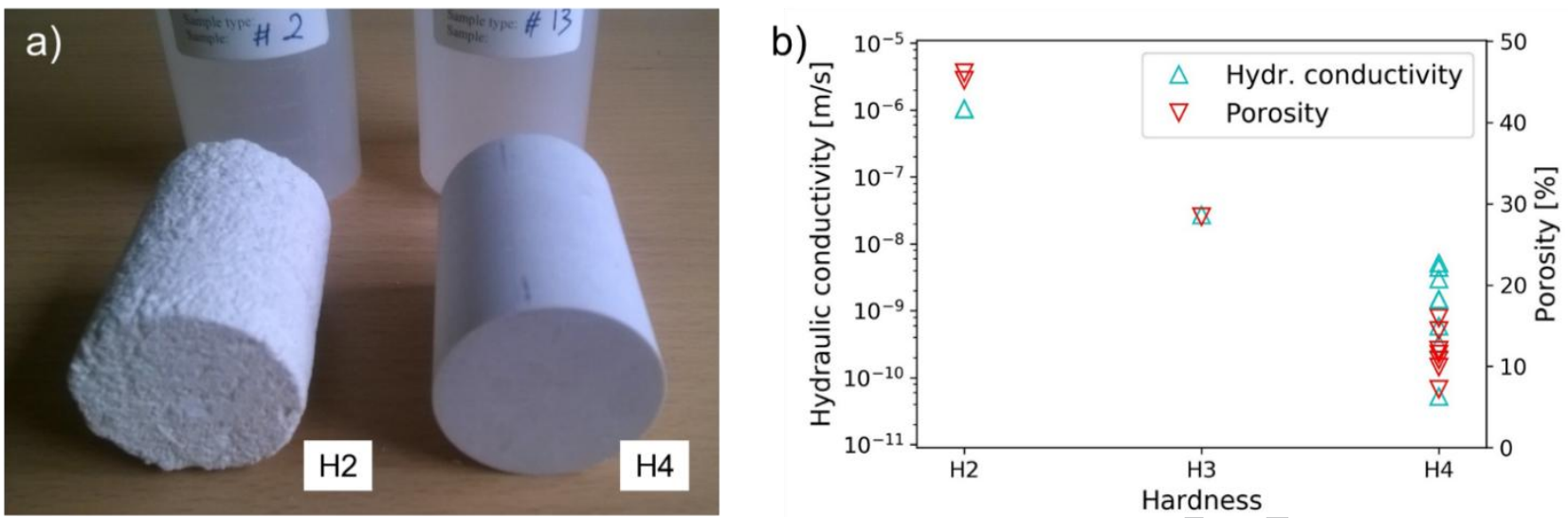

Figure 7a) Photo of a grainy limestone subcore $(\varnothing 3.7 \mathrm{~cm}$ ) from the Akacievej site with hardness $\mathrm{H} 2$ (left) and a more cemented one with hardness $\mathrm{H} 4$ (right), illustrating the different structures of the limestone matrix. The subcores were used in the Poroperm tests. b) Hydraulic conductivity $\mathrm{K}$ and porosity for limestone with hardness $\mathrm{H} 2, \mathrm{H} 3$ and $\mathrm{H} 4$ determined with Poroperm tests. The hydraulic conductivity and porosity are correlated and can be related to the hardness of the limestone: Softer limestone has a higher porosity and hydraulic conductivity.

\section{4.2. Transport behavior from tracer test in limestone units}

The transport behavior of the three units of the limestone aquifer was investigated by employing six

534 tracer tests, of which two included simultaneous injection of multiple tracers. The tracer tests were conducted

535 in combination with the long-term pumping test (see overview of experiments in Figure 4). For the further

536 discussion, the tracer tests were grouped according to their breakthrough characteristics (Table 5) and temporal moments were calculated. 
Table 5: Overview of tracer injections, location of the screen of the injection well (crushed C, upper fractured UF, lower fractured LF) and tracer recovery. The tracers sulforhodamine B (SRB), fluorescein (FL), lithium and bromide were injected. A combination of fluorescein and lithium bromide was injected in G19d and G18s_pre. The tracer tests were grouped according to their breakthrough behavior: group 1 has a fast breakthrough, high peak concentrations and a high recovery, group 2 has a later tracer arrival, lower peak concentrations, a longer breakthrough and lower recovery. The tracer test G18s_pre is group 3. The temporal moments were analyzed to characterize the breakthrough curves.

\begin{tabular}{|c|c|c|c|c|c|c|c|c|c|c|}
\hline $\begin{array}{l}\text { Injection } \\
\text { well screen }\end{array}$ & Group & $\begin{array}{l}\text { Aquifer } \\
\text { unit }\end{array}$ & Tracer & Peak c & $\begin{array}{l}\text { Peak } \\
\mathrm{c} \\
\text { arrival } \\
\text { time } \\
\end{array}$ & $\begin{array}{l}\text { Max } \\
\text { transport } \\
\text { velocity }\end{array}$ & $\begin{array}{l}\text { Mean } \\
\text { effective } \\
\text { transport } \\
\text { velocity }^{2}\end{array}$ & $\begin{array}{l}\text { Spread } \\
\text { of BT } \\
\text { curve }\end{array}$ & Skewness & Recovery \\
\hline & & & & $\%$ of inj c & $\mathrm{h}$ & $\mathrm{m} / \mathrm{h}$ & $\mathrm{m} / \mathrm{h}$ & & & $\%$ \\
\hline G18s & 1 & UF & SRB & 3.71 & 0.83 & 30.0 & 1.31 & 143 & 9861 & 98 \\
\hline \multirow[t]{3}{*}{ G19d } & 1 & UF & FL & 1.80 & 1.67 & 30.0 & 3.02 & 106 & 256 & 83 \\
\hline & & & $\mathrm{Li}$ & 1.87 & 1.67 & 30.0 & 2.26 & 185 & 10934 & 100 \\
\hline & & & $\mathrm{Br}$ & 1.09 & 1.83 & 30.0 & 2.33 & 159 & 8489 & 57 \\
\hline G5 & 1 & $\mathrm{C}+\mathrm{UF}$ & SRB & 3.04 & 0.75 & 26.0 & 0.48 & 599 & 27991 & $116^{3}$ \\
\hline G18d & 2 & $\mathrm{LF}$ & SRB & 0.09 & 4.00 & - & 0.20 & 688 & 23339 & 15 \\
\hline PB & 2 & $\mathrm{C}(+\mathrm{UF})$ & FL & 0.17 & 3.26 & 9.4 & 0.27 & 1285 & 98127 & 72 \\
\hline \multirow[t]{3}{*}{ G18s_pre } & 3 & UF & FL & 0.06 & 0.00 & - & .17 & 879 & 37154 & $18^{4}$ \\
\hline & & & $\mathrm{Li}$ & 0.05 & 0.00 & - & & - & - & $(4)^{4}$ \\
\hline & & & $\mathrm{Br}$ & 0.04 & 0.00 & & 0.13 & 1199 & 47234 & $16^{4}$ \\
\hline
\end{tabular}

544 The maximum transport velocity was calculated by dividing the distance between injection and pumping well by the arrival time of $5451 \%$ of the peak concentration

5462 The mean effective transport velocity was calculated by dividing the distance between injection and pumping well by the arrival 547 time of the center of mass

$548{ }^{3}$ The recovery $>100 \%$ could be due to the analytical accuracy of the spectrophotometer and the general sampling uncertainty

$549{ }^{4}$ Recovery was evaluated for the first 48 hours, until the next tracer was injected in G18s. The results are very uncertain, because 550 Lithium concentrations measured for G18s_pre were very close to the detection limit.

\subsubsection{Horizontal fracture-dominated transport}

The screens of the injection wells in group 1 were located at similar depths in the upper fractured limestone as the pumping well screen (G17), and major horizontal fractures clearly dominate the tracer transport between injection wells and the extraction well. The tracer tests in group 1 (Figure 8a) exhibited high peak concentrations of 1 to $3.7 \%$ of the injected concentration, an early peak arrival time and a high maximum transport velocity (Table 5). The breakthrough curves for G18s and G19d show little tailing, 
tracer recoveries in group 1 were relatively high (57-100\%), and tracer losses were mainly due to diffusion 562 into the limestone matrix.

The spreading and skewness determined by temporal moment analysis in group 1 (Table 5) was 564 generally relatively low. However, the tracer test in G5 showed an unusually high spreading and skewness of 565 the breakthrough curve, higher than for all other tracer tests (including group 2 and 3). A reason for this is 566 probably the long screen of G5, which spans across the crushed and the upper fractured limestone units, 567 whereas G18s and G19d are screened in the upper fractured unit only. The tracer test in G5 yielded a high 568 peak concentration and a long tailing with low concentrations, which shows that the tracer in the lower part 569 of the well moved fast through horizontal fractures to the pumping well, whereas tracer in the upper part of 570 the G5 migrated much slower due to the lower hydraulic conductivity in the crushed limestone unit.

571 The tracer tests in group 1 demonstrate that major horizontal fractures constitute fast transport 572 pathways and provide a good connectivity within the upper fractured limestone unit. In the time frame of the conducted tracer tests, the influence of matrix diffusion on the tracer transport was comparatively small, and most of the injected tracer could be retrieved. 

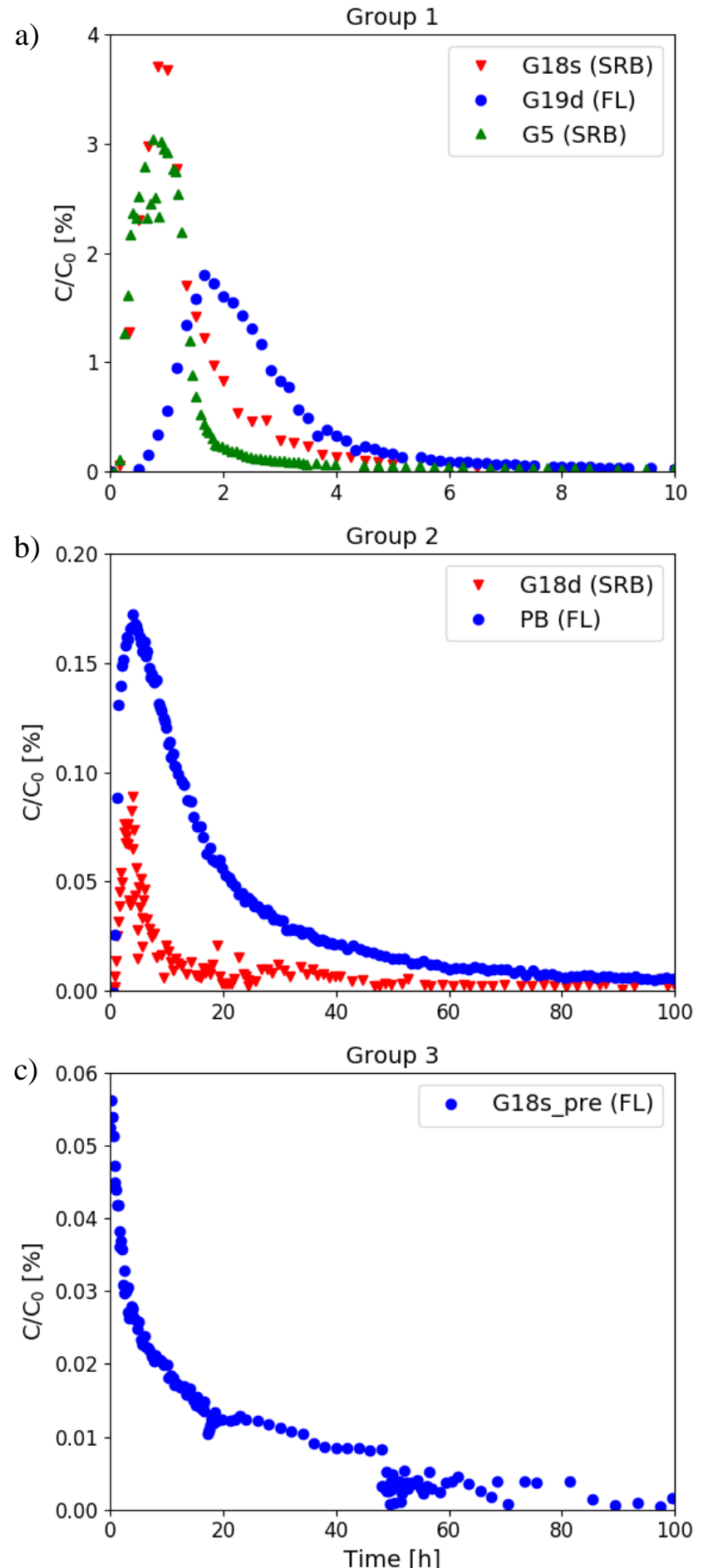

Figure 8: The fluorescent tracer concentrations (SRB: sulforhodamine B, FL: fluorescein) measured at the pumping well normalized with the injection concentration are shown. The tracer breakthrough curves were grouped according to breakthrough characteristics (Table 5). Note that the time scale on Figure 7a (group 1) is much shorter than on Figure $7 \mathrm{~b}$ and c (groups 2 and 3). The jump in the concentration after $48 \mathrm{~h}$ on Figure $7 \mathrm{c}$ is due to the injection of a different tracer in the same well, which diluted the tracer and influenced the flow field. 


\subsubsection{Vertical connectivity in the limestone aquifer}

Considerably lower peak concentrations (ca. $0.1 \%$ of the injected concentrations) and a much longer tailing were observed in the tracer breakthrough curves of group 2 (Figure 8b). Tracers were injected at well screens in different aquifer units than the pumping well screen, hence, the vertical transport properties became important. The well PB was mainly screened in the crushed limestone above the pumping well and intercepts only the uppermost fracture in the fractured limestone, while G18d was screened in the lower fractured limestone, with no major horizontal fracture connecting to G17. Despite having a similar horizontal distance to the pumping well as G18s and G5 from group 1, the peak arrival time at the pumping well was about four times as long (ca. $4 \mathrm{~h}$ ) for the tracer tests in group 2, and the maximum transport velocity was by a factor of 3 smaller.

The recovery for the tracer test in G18d (in the lower fractured unit) was low (15\%). One reason for this low recovery is, that within the long travel time, a greater part of the tracer had diffused into the matrix and could not be retrieved in the limited time of the tracer test. More importantly, tracer was transported downstream with the natural groundwater flow by major horizontal fractures that are not connected to the pumping well screen in the upper fractured limestone unit. Hence, the tracer was not captured by the pumping well, which primarily withdraws water from fractures intersecting its well screen. This indicates that the vertical/subvertical joints have small apertures and do not significantly contribute to the local groundwater flow, compared to the preferential transport in major horizontal fractures.

The tracer test in PB had a relatively high tracer recovery $(72 \%)$. This indicates that the upper fractured and the crushed limestone unit are connected, and the flow field in the crushed limestone unit is affected by pumping in the upper fractured unit. However, the vertical flow from the crushed layer to the upper fractured aquifer unit is slow and the conductivity of the crushed limestone is lower than in the fractured units, hence the tracer spreads slowly and tracer breakthrough is slow. The breakthrough curve also shows a long tailing, characteristic for dual-continuum or highly-heterogeneous aquifers (Carrera et al., 1998; Pedretti et al., 2013). Based on the low maximum transport velocity, it can be inferred that the conductivity in the crushed limestone is lower than in the upper fractured unit and that vertical joints 
between crushed and upper fractured limestone have smaller apertures or may be filled with fine material, as reported in Jakobsen and Klitten (1999).

The second set of tracer tests provided evidence that the transport in the aquifer predominantly occurs in major horizontal fractures and that the vertical fractures have smaller apertures. Consequently, the vertical advective transport of substances is restricted, and substances are predominately transported in relatively narrow depth intervals guided by major horizontal fractures and flint layers.

\subsubsection{Matrix diffusion effects}

Matrix diffusion is most relevant for the tracer test G18s_pre, which was initiated under natural gradient conditions, four days before starting to pump. This test shows a significantly different breakthrough behavior (Figure 8c) to the other tracer tests which were injected while pumping. The expectation based on modeling was that it would take several hours before the tracer arrived at the pumping well. However, despite G18s being located downgradient of the pumping well (with respect to the regional groundwater flow), very low tracer concentrations were already detected at the pumping well as the pump was switched on four days after the injection. This showed that the tracer injection at G18s had caused tracer transport even against the dominating flow direction in the fractures, and well beyond the pumping well G17.

The pumping at well G17 considerably changed the flow field and a part of the tracer from G18s_pre in the fractures was drawn towards the pumping well, while tracer in the matrix diffused back to the fractures as well as further into the matrix. After the pump was switched on, the observed tracer concentrations steadily decreased and the breakthrough curve shows a very long tailing.

Only a small part of the injected tracer from G18s_pre could be retrieved, because in the four days without pumping, the tracer had spread downstream with the fast flow in the fractures under natural gradient groundwater flow conditions. By the time the pump was started, a part of the tracer was already outside the zone of influence of the pumping well and could not be drawn back. Moreover, the tracer that had already diffused into the matrix could steadily diffuse further into the matrix, hence it was only slowly retrieved, revealing a low back-diffusion rate. This indicates that advective transport occurs mainly in a few major 
632 fractures with a relatively large fracture spacing. The long tailing of the breakthrough curve is due to back-

633 diffusion of tracer from the limestone matrix.

634 4.2.4. Species-dependent breakthrough behavior

To further investigate the matrix diffusion behavior, the tracers fluorescein, lithium and bromide with

636 different diffusion properties (see Table SI-1) were simultaneously injected in two tracer tests (G18s_pre and 637 G19d). All three tracers were monitored at the pumping well. In the tracer test in G19d, bromide and the 638 other two tracers exhibited clear differences in their breakthrough behavior (Figure 9). The peak arrival time 639 for fluorescein and lithium (100 $\mathrm{min})$ was shorter than for bromide $(110 \mathrm{~min})$. The analysis of the first 640 temporal moment resulted in a higher mean effective transport velocity for fluorescein $(3.0 \mathrm{~m} / \mathrm{h})$ than for 641 bromide and lithium $(2.3 \mathrm{~m} / \mathrm{h})$. The breakthrough curve of lithium and bromide also showed more spreading and a stronger skewness (indicated by larger second and third central moments) than fluorescein, and the 643 peak concentration for bromide was ca. $40 \%$ lower than for fluorescein and lithium. 

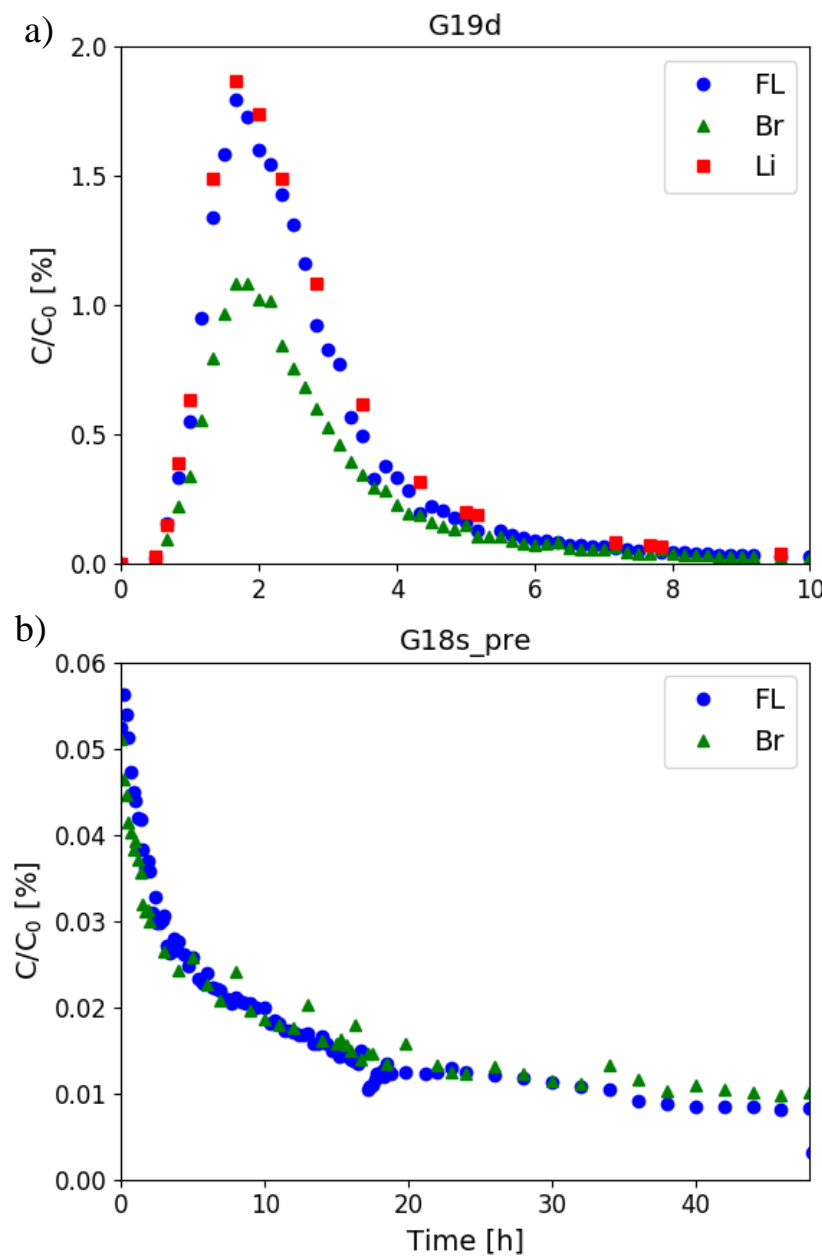

Figure 9a) Tracer BTCs (concentrations normalized with injection concentration) for fluorescein, bromide and lithium when simultaneously injected in G19d. Bromide had a considerably lower peak concentration due to a stronger matrix diffusion than the other two tracers. b) Tracer breakthrough curves for fluorescein and bromide for the tracer test G18s_pre. The time axis starts with 0 when the pump was started. The two tracers show a similar breakthrough behavior with a slightly stronger matrix diffusion for bromide.

The differences between the breakthrough curves can be explained by the different diffusion behavior of the simultaneously injected tracers. Bromide has the highest molecular diffusion coefficient of the three tracers, leading to a stronger matrix diffusion. The back-diffusion rate from matrix to fractures is so low that the total recovery of bromide (ca. $57 \%$ ) after 4.3 days was considerably lower than lithium (ca. $100 \%$ ) and fluorescein (ca. $83 \%$ ). This clearly shows the importance of matrix diffusion in the considered aquifer, since the different breakthrough behavior of the tracer species cannot be explained by aquifer heterogeneity and the effect of sorption on the limestone matrix was evaluated to be low for all three tracers.

The differences in the breakthrough behavior for fluorescein and bromide were smaller in the tracer test G18s_pre (initiated before pumping). This could be expected, because in fractured systems, backdiffusion generally occurs at lower rates than the diffusion of a substance from the fractures into the matrix. 
660 When a substance initially spreads in the fast fracture flow, the concentration gradients from the fractures to

661 the adjacent matrix are strong, and the tracer transported within the fractures is subject to strong diffusion

662 into the matrix. Once diffused into the matrix and there is clean water flowing through the fractures, the

663 tracer next to the fractures diffuses back. However, there can still be concentration gradients further into the

664 matrix, lowering the actual back-diffusion rate. Hence, the G18s_pre test does not show a difference between

665 the different tracers as pronounced as in the tracer test in G19d, where diffusion is mainly acting from the

666 fractures into the matrix. Moreover, the mean effective transport velocity of fluorescein is higher than the

667 one of bromide and the spreading and skewness of the breakthrough curve of fluorescein is smaller. This

668 indicates less matrix diffusion, as expected based on the molecular diffusion coefficients of the tracers (Table

669 SI-1).

670 4.3. Conceptual model for the limestone aquifer units

671 The combined interpretation of hydraulic tests and tracer tests in different units allowed for a detailed

672 characterization of the limestone aquifer units at the Akacievej site, and for the development of an improved

673 conceptual site model (Figure 10). 


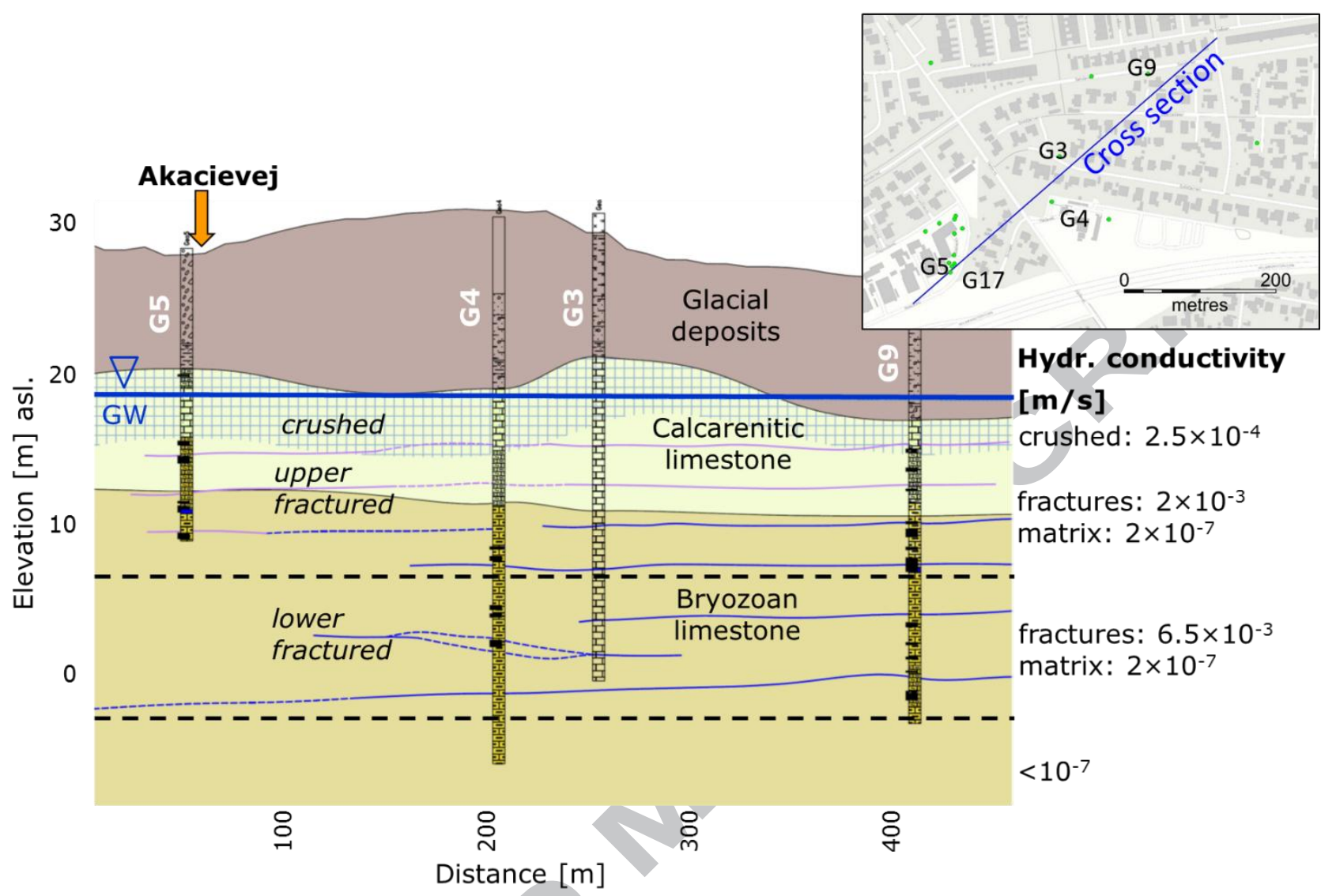

Figure 10: Revised geologic cross section at the Akacievej site, approximate location of the groundwater (GW) table in May 2015 and location of horizontal fractures and chert layers, inferred from the combination of aquifer tests. The arrow indicates the location of the Akacievej site. Average hydraulic conductivities are shown on the right and indicate strong hydraulic conductivity contrasts between crushed limestone, fractured limestone and the relatively intact limestone below. The dual-continuum hydraulic conductivities in the fractured limestone units show a strong contrast between fracture and matrix continuum.

\subsubsection{Crushed limestone}

The crushed limestone unit at the Akacievej site (upper 2 to $5 \mathrm{~m}$ of the limestone aquifer) is glacially disturbed and consists of calcarenitic limestone clusters from the Copenhagen limestone formation with cluster sizes down to $1 \mathrm{~cm}$ (Galsgaard et al., 2014). The average hydraulic conductivity in the crushed aquifer unit was an order of magnitude lower compared to the upper fractured limestone unit. This indicates that the crushed limestone does not provide the fast flow pathways (major fractures) observed in the fractured limestone unit. The crushed limestone can be considered as a disturbed medium with few hydraulically active fractures of limited aperture. The fractures are potentially filled with fine material like sand, silt and clays from glacial deposits (Galsgaard et al., 2014). Hence, substances will spread relatively slowly in this unit. The pumping test showed a connectivity between the crushed and the upper fractured limestone. However, the tracer test in PB revealed a slow vertical transport from the crushed to the fractured 
unit. The relatively high tracer recovery suggests that matrix diffusion has less effect on solute transport in

692 the crushed limestone unit than in the fractured units.

693

694

695

696

697

698

\subsubsection{Upper fractured limestone}

The upper fractured limestone contains calcarenitic limestone and bryozoan limestone, which demonstrate similar properties at the Akacievej site. Long horizontal fractures (several hundred meters) with relatively large apertures of a few millimeters were identified in this aquifer unit. These large fractures dominate the flow, while vertical and subvertical fractures with smaller apertures or filled with fine glacial deposits provide little vertical connectivity in the aquifer. Thin horizontal chert layers and nodules were observed, and these impede vertical flow. The limestone matrix is very heterogeneous with a wide range of hydraulic conductivities and porosities. However, the strong hydraulic conductivity contrast between fractures and matrix has a major impact on solute transport. Substances primarily spread with the flow in major fractures, and diffuse from the fractures into the comparably stagnant water in the limestone matrix.

\subsubsection{Lower fractured limestone}

The lower fractured limestone consists of bryozoan limestone, and has similar properties to the upper fractured limestone. Opposed to calcarenitic limestone, bryozoan limestone often has bank structures (references), hence different hydraulic properties were expected. Surprisingly, no bank structures were identified and the hydraulic tests yielded similar flow properties for the two types of limestone. The flow log in G18d, the double-packer tests and the optical televiewer measurements allowed for the identification of some major, hydraulically active horizontal fractures with hydraulic apertures up to $3 \mathrm{~mm}$ in the lower fractured limestone unit. They provide an overall horizontal conductivity similar to or even higher than in the upper fractured limestone. Chert layers and nodules were also detected on the optical televiewer images in this limestone unit. Vertical and subvertical fractures provide only limited connections between upper and lower fractured limestone, as observed in the breakthrough curve for the tracer test in G18d (Figure 8b). This indicates few vertical/subvertical fractures with small apertures, potentially filled with fine material. Hence, also in the lower fractured limestone unit, substances spread predominantly along major horizontal fractures. 
The deepest localized hydraulically active fractures in the aquifer could be determined by the impeller flow logging in G18d (partly shown in Figure 6), which shows no major flow zones between depths of $-7 \mathrm{~m}$ asl and $-16.5 \mathrm{~m}$ asl, with no evidence of hydraulically active zones. Hence, G18d showed that the vertical extent of the hydraulically active part of the aquifer is approximately $26 \mathrm{~m}$ (aquifer thickness).

\subsection{Discussion of major findings}

In complex limestone geologies with different aquifer units, a combination of depth-specific aquifer tests, as developed in this study, is required, because the individual tests give complementary information about flow and transport processes in the different aquifer units and allow for the characterization of both fractures and low-permeability limestone matrix. The solute transport behavior including matrix diffusion can only be analyzed based on tracer tests implying heat or chemical tracers, which also reveal the connectivity of different aquifer units and wells, or by analyzing the transport behavior of naturally occurring substances and contaminants in the aquifer.

The placement of well screens for pumping and tracer injections should be in accordance with the objective of the investigation. To analyze the horizontal transport behavior, well screens at the same depth are useful, whereas vertical transport properties can be studied with well screens at different depths and in different aquifer units, yielding information about the connectivity of the aquifer units. It is important to note that forced- gradient tracer tests may activate additional flow paths (Butler et al. (2009)) compared to natural fluorescent and ionic tracers with different diffusion properties. The multiple-tracer tests were particularly useful to analyze the matrix diffusion behavior in the fractured limestone aquifer and revealed a speciesdependent transport behavior, when injected while pumping. The species-specific tracer breakthrough allowed the effect of matrix diffusion on solute transport to be distinguished from aquifer heterogeneity, as 
suggested by Carrera et al. (1998). Simultaneous injection of multiple tracers is therefore recommended when conducting tracer tests in fractured geologies. Modeling concepts incorporating species-dependent transport (e.g. Nelson et al., 2003; Rolle et al., 2013) have to be further developed for fractured limestone geologies and incorporated in field-site contaminant transport models for contaminated site risk assessment and planning of remedial actions.

\section{Conclusions}

Comprehensive and complementary data on the flow and transport processes in different units of a limestone aquifer and on the connectivity between the aquifer units was obtained from a combination of depth-specific tracer tests, pumping tests and borehole and hydraulic aquifer tests. In contrast to many previous studies, multiple tracer species with different diffusion properties were simultaneously injected and screens located in different aquifer units were used for the tracer injections to obtain information about horizontal and vertical transport properties. A new and stronger conceptual understanding for the hydrogeological units was developed based on the experimental results.

Very complementary and consistent information about the hydraulic properties in the aquifer units was obtained from the borehole and hydraulic aquifer tests. A strong contrast in hydraulic conductivity between fractures and matrix was observed in both the upper and lower fractured limestone unit, which turned out to have similar hydraulic properties. A crushed upper limestone layer, an upper fractured and a lower fractured aquifer unit were analyzed, revealing clear differences between the more conductive fractured limestone and the less conductive crushed limestone.

A distinct preferentially horizontal transport along major fractures with limited vertical connectivity between the upper and lower fractured limestone unit was identified based on the tracer tests. The tests showed that vertical fractures have less influence on solute transport, probably because they have small apertures or are filled with fine material. Multi-tracer experiments provided additional insights to the matrix diffusion behavior in the fractured limestone units. The low peak concentrations at the pumping well and the long breakthrough curve tailing observed in the tracer test initiated prior to pumping revealed significant 
tracer diffusion from the fractures into the matrix. The back-diffusion, however, was slow due to a concurrent continuous diffusion further into the matrix. When injected during pumping, bromide was much more subject to matrix diffusion than fluorescein, which has a lower diffusion coefficient. The solute transport behavior could not have been inferred from the borehole and hydraulic aquifer tests alone and therefore the tracer tests are necessary when developing site develop specific and general conceptual understanding of limestone settings at a scale relevant for contaminated sites.

\section{Acknowledgements}

The authors are grateful for useful discussions with Michael D. Annable during the design of the experiments and Peter Roll Jakobsen from the Geological Survey of Denmark and Greenland (GEUS) for his help with the initial geologic interpretation. The technicians Bent Henning Skov, Jens Schaarup Sørensen, Flemming Møller, Erik Rønn Lange, Satomi Matsuura, Hanne Bøggild and analytical chemist Mikael Emil Olsson, and the students Pau Revilla Besora, Theodora Tsitseli and David Collet participated in the development, construction, and application of the injection and sampling system, field sampling, sample characterization, and chemical analyses. These contributions are gratefully acknowledged. This work was funded by the Capital Region of Denmark and the Technical University of Denmark.

\section{Literature}

Ackerer, P., Delay, F., 2010. Inversion of a set of well-test interferences in a fractured limestone aquifer by using an automatic downscaling parameterization technique. J. Hydrol. 389, 42-56. https://doi.org/10.1016/j.jhydrol.2010.05.020

Aisopou, A., Binning, P.J., Albrechtsen, H.J., Bjerg, P.L., 2015. Modeling the Factors Impacting Pesticide Concentrations in Groundwater Wells. Groundwater 53, 722-736. https://doi.org/10.1111/gwat.12264

Barker, J.A., 1988. A generalized radial flow model for hydraulic tests in fractured rock. Water Resour. Res. 24, 1796-1804. https://doi.org/10.1029/WR024i010p01796

Basiricò, S., Crosta, G.B., Frattini, P., Villa, A., Godio, A., 2015. Borehole Flowmeter Logging for the Accurate Design and Analysis of Tracer Tests. Groundwater 53, 3-9. 
https://doi.org/10.1111/gwat.12293

Becker, M.W., Shapiro, A.M., 2003. Interpreting tracer breakthrough tailing from different forced-gradient tracer experiment configurations in fractured bedrock. Water Resour. Res. 39, n/a-n/a. https://doi.org/10.1029/2001WR001190

Berkowitz, B., 2002. Characterizing flow and transport in fractured geological media: A review. Adv. Water Resour. 25, 861-884. https://doi.org/10.1016/S0309-1708(02)00042-8

Black, J.H., Kipp, K.L., 1983. Movement of tracers through dual-porosity media - Experiments and modelling in the Cretaceous Chalk, England. J. Hydrol. 62, 287-312. https://doi.org/10.1016/00221694(83)90108-7

Bottrell, S.H., Thornton, S.F., Spence, M.J., Allshorn, S., Spence, K.H., 2010. Assessment of the use of fluorescent tracers in a contaminated Chalk aquifer. Q. J. Eng. Geol. Hydrogeol. 43, 195-206. https://doi.org/10.1144/1470-9236/08-020

Broholm, M.M., Janniche, G.S., Mosthaf, K., Fjordbøge, A.S., Binning, P.J., Christensen, A.G., Grosen, B., Jørgensen, T.H., Keller, C., Wealthall, G., Kerrn-Jespersen, H., 2016. Characterization of chlorinated solvent contamination in limestone using innovative FLUTe technologies in combination with other methods in a line of evidence approach. J. Contam. Hydrol. 189, 68-85. https://doi.org/10.1016/j.jconhyd.2016.03.007

Butler, A.P., Mathias, S.A., Gallagher, A.J., Peach, D.W., Williams, A.T., 2009. Analysis of flow processes in fractured chalk under pumped and ambient conditions (UK). Hydrogeol. J. 17, 1849-1858. https://doi.org/10.1007/s10040-009-0477-4

Butler, J.J.J., Healey, J.M., 1998. Relationship between pumping-test and slug-test parameters: Scale effect of artifact? Ground Water 36, 305-313.

Carrera, J., Sánchez-Vila, X., Benet, I., Medina, A., Galarza, G., Guimerà, J., 1998. On matrix diffusion: formulations, solution methods and qualitative effects. Hydrogeol. J. 6, 178-190. https://doi.org/10.1007/s100400050143

Cirpka, O.A., Kitanidis, P.K., 2000. Characterization of mixing and dilution in heterogeneous aquifers by means of local temporal moments. Water Resour. Res. 36, 1221-1236. 
Cussler, E.L., 2011. Diffusion. Mass transfer in fluid systems.

Doro, K.O., Cirpka, O.A., Leven, C., 2015. Tracer Tomography: Design Concepts and Field Experiments Using Heat as a Tracer. Groundwater 53, 139-148. https://doi.org/10.1111/gwat.12299

Downing, R.A., Price, M., Jones, G.P., 1993. The hydrogeology of the Chalk of North-West Europe. Clarendon Press, Oxford.

Duffield, G.M., 2007. AQTESOLV for Windows.

Galsgaard, J., Rohde, M.M., Jakobsen, R., Jakobsen, P.R., 2014. Strømning og stoftransport i kalklagene på den københavnske vestegn - Geologisk og hydrologisk vidensopsamling og typemodel.

Govindaraju, R.S., Das, B.S., 2007. Moment analysis for subsruface hydrologic applications. Springer, Dordrecht.

Hartmann, S., Odling, N.E., West, L.J., 2007. A multi-directional tracer test in the fractured Chalk aquifer of E. Yorkshire, UK. J. Contam. Hydrol. 94, 315-331. https://doi.org/10.1016/j.jconhyd.2007.07.009

Illman, W.A., 2013. Hydraulic Tomography Offers Improved Imaging of Heterogeneity in Fractured Rocks. Groundwater 52, 659-684. https://doi.org/10.1111/gwat.12119

Ireson, A.M., Mathias, S.A., Wheater, H.S., Butler, A.P., Finch, J., 2009. A model for flow in the chalk unsaturated zone incorporating progressive weathering. J. Hydrol. 365, 244-260. https://doi.org/10.1016/j.jhydrol.2008.11.043

Jakobsen, P.R., Klitten, K., 1999. Fracture systems and groundwater flow in the Kobenhavn Limestone Formation. Nord. Hydrol. 30, 301-316.

Jakobsen, P.R., Rohde, M.M., Sheldon, E., 2017. Structures and stratigraphy of Danian limestone, eastern Sjælland, Denmark. Geol. Surv. Denmark Greenl. Bull. 38, 21-24.

Jakobsen, R., Jensen, K.H., Brettmann, K.L., 1993. Tracer test in fractured chalk 1. Experimental design and results. Nord. H 24, 263-274.

Jardine, P.M., Sanford, W.E., Gwo, J.P., Reedy, O.C., Hicks, D.S., Riggs, J.S., Bailey, W.B., 1999. Quantifying diffusive mass transfer in fractured shale bedrock. Water Resour. Res. 35, 2015-2030. https://doi.org/10.1029/1999WR900043

Keller, C., 2016. A New Rapid Method for Measuring the Vertical Head Profile. Groundwater 55, $244-254$. 
https://doi.org/10.1111/gwat.12455

Klammler, H., Hatfield, K., Newman, M.A., Cho, J., Annable, M.D., Parker, B.L., Cherry, J.A., Perminova, I., 2016. A new device for characterizing fracture networks and measuring groundwater and contaminant fluxes in fractured rock aquifers. Water Resour. Res. 52, 5400-5420. https://doi.org/10.1002/2015WR018389

Klepikova, M. V., Le Borgne, T., Bour, O., Gallagher, K., Hochreutener, R., Lavenant, N., 2014. Passive temperature tomography experiments to characterize transmissivity and connectivity of preferential flow paths in fractured media. J. Hydrol. 512, 549-562. https://doi.org/10.1016/j.jhydrol.2014.03.018

Kruseman, G.P., de Ridder, N. a., 1990. Analysis and evalution of pumping test data.

Larsen, G., Frederiksen, J., Villumsen, A., Fredericia, J., Gravesen, P., Foged, N., Knudsen, B., Baumannn, J., 1995. A guide to engineering geological soil description. Danish Geotechnical Society.

LeBlanc, D., Garabedian, S.P., Hess, K.M., Gelhar, L.W., Quadri, R.D., Stollenwerk, K.G., Wood, W.W., 1991. Large-scale natural gradient tracer test in sand and gravel, Cape Cod, Massachusetts - 1. Experimental Design and observed tracer movement. Water Resour. Res. 27, 895-910.

Levi, S., Hybel, A.M., Bjerg, P.L., Albrechtsen, H.J., 2014. Stimulation of aerobic degradation of bentazone, mecoprop and dichlorprop by oxygen addition to aquifer sediment. Sci. Total Environ. 473-474, 667675. https://doi.org/10.1016/j.scitotenv.2013.12.061

Lloyd, J.W., Greswell, R., Williams, G.M., Ward, R.S., Mackay, R., Riley, M.S., 1996. An integrated study of controls on solute transport in the Lincolnshire limestone. Q. J. Eng. Geol. 29, 321-339. https://doi.org/10.4135/9781412950558.n200

Macdonald, A.M., Allen, D.J., 2001. Aquifer properties of the Chalk of England. Q. J. Eng. Geol. Hydrogeol. 34, 371-384.

Marella, R., Berndt, M., 2005. Water withdrawals and trends from the Floridan aquifer system in the southeastern United States, 1950-2000. USGS Geol. Surv. Circ. 1278.

Maurice, L., Barker, J.A., Atkinson, T.C., Williams, A.T., Smart, P.L., 2011. A Tracer Methodology for Identifying Ambient Flows in Boreholes. Ground Water 49, 227-238. https://doi.org/10.1111/j.1745$6584.2010 .00708 . x$ 
Maurice, L.D., Atkinson, T.C., Barker, J.A., Williams, A.T., Gallagher, A.J., 2012. The nature and distribution of flowing features in a weakly karstified porous limestone aquifer. J. Hydrol. 438-439, 315. https://doi.org/10.1016/j.jhydrol.2011.11.050

Moench, A.F., 1984. Double-porosity models for a fissured groundwater reservoir with fracture skin. Water Resour. Res. 20, 831. https://doi.org/10.1029/WR020i007p00831

Molz, F.J., Morin, R.H., Hess, A.E., Melville, J.G., Güven, O., 1989. The impeller meter for measuring aquifer permeability variations: Evaluation and comparison with other tests. Water Resour. Res. 25, $1677-1683$.

Neuman, S.P., 2005. Trends, prospects and challenges in quantifying flow and transport through fractured rocks. Hydrogeol. J. 13, 124-147. https://doi.org/10.1007/s10040-004-0397-2

Nielsen, K.A., 2007. Fractured aquifers.

Odling, N.E., West, L.J., Hartmann, S., Kilpatrick, A., 2013. Fractional flow in fractured chalk; a flow and tracer test revisited. J. Contam. Hydrol. 147, 96-111. https://doi.org/10.1016/j.jconhyd.2013.02.003

Paillet, F.L., 1998. Flow modeling and permeability estimation using borehole flow logs in heterogeneous fractured formations. Water Resour. Res. 34, 997-1010. https://doi.org/10.1029/98WR00268

Pedretti, D., Fernàndez-Garcia, D., Bolster, D., Sanchez-Vila, X., 2013. On the formation of breakthrough curves tailing during convergent flow tracer tests in three-dimensional heterogeneous aquifers. Water Resour. Res. 49, 4157-4173. https://doi.org/10.1002/wrcr.20330

Pehme, P., Parker, B.L., Cherry, J. a., Blohm, D., 2014. Detailed measurement of the magnitude and orientation of thermal gradients in lined boreholes for characterizing groundwater flow in fractured rock. J. Hydrol. 513, 101-114. https://doi.org/10.1016/j.jhydrol.2014.03.015

Price, M., Downing, R.A., Edmunds, W.M., 1993. The Chalk as an aquifer, in: Downing, R.A., Price, M., Jones, G.P. (Eds.), The Hydrogeology of the Chalk of North-West Europe. Clarendon Press, Oxford, pp. 35-58.

Ptak, T., Teutsch, G., 1994. Forced and natural gradient tracer tests in a highly heterogeneous porous aquifer: instrumentation and measurements. J. Hydrol. 159, 79-104. https://doi.org/10.1016/00221694(94)90250-X 
Qian, J., Zhou, X., Zhan, H., Dong, H., Ma, L., 2014. Numerical simulation and evaluation of groundwater resources in a fractured chalk aquifer: a case study in Zinder well field, Niger. Environ. Earth Sci. 72, 3053-3065. https://doi.org/10.1007/s12665-014-3211-z

Riley, M.S., Ward, R.S., Greswell, R.B., 2001. Converging flow tracer tests in fissured limestone. Q. J. Eng. Geol. Hydrogeol. 34, 283-297. https://doi.org/10.1144/qjegh.34.3.283

Sanchez-León, E., Leven, C., Haslauer, C.P., Cirpka, O. a., 2015. Combining 3D Hydraulic Tomography with Tracer Tests for Improved Transport Characterization. Groundwater n/a-n/a. https://doi.org/10.1111/gwat.12381

Sánchez-Vila, X., Carrera, J., 2004. On the striking similarity between the moments of breakthrough curves for a heterogeneous medium and a homogeneous medium with a matrix diffusion term. J. Hydrol. 294, 164-175. https://doi.org/10.1016/j.jhydrol.2003.12.046

Smart, P.L., Laidlaw, I.M.S., 1977. An evaluation of some fluorescent dyes for water tracing. Water Resour. Res. 13, 15. https://doi.org/10.1029/WR013i001p00015

Somogyvári, M., Bayer, P., 2017. Field validation of thermal tracer tomography for reconstruction of aquifer heterogeneity. Water Resour. Res. 53. https://doi.org/10.1002/2017WR020543

Somogyvári, M., Bayer, P., Brauchler, R., 2016. Travel-time-based thermal tracer tomography. Hydrol. Earth Syst. Sci. 20, 1885-1901. https://doi.org/10.5194/hess-20-1885-2016

Trottier, N., Delay, F., Bildstein, O., Ackerer, P., 2014. Inversion of a dual-continuum approach to flow in a karstified limestone: Insight into aquifer heterogeneity revealed by well-test interferences. J. Hydrol. 508, 157-169. https://doi.org/10.1016/j.jhydrol.2013.10.039

Vangkilde-Pedersen, T., Mielby, S., Jakobsen, P.R., Hansen, B., Iversen, C.H., Nielsen, A.M., 2011. Kortlægning af kalkmagasiner. Copenhagen.

Wagner, V., Li, T., Bayer, P., Leven, C., Dietrich, P., Blum, P., 2014. Thermal tracer testing in a sedimentary aquifer: Field experiment (Lauswiesen, Germany) and numerical simulation. Hydrogeol. J. 22, 175187. https://doi.org/10.1007/s10040-013-1059-z

West, L.J., Odling, N.E., 2007. Characterization of a multilayer aquifer using open well dilution tests. Ground Water 45, 74-84. https://doi.org/10.1111/j.1745-6584.2006.00262.x 
928 Williams, A., Bloomfield, J., Griffiths, K., Butler, A., 2006. Characterising the vertical variations in 929 hydraulic conductivity within the Chalk aquifer. J. Hydrol. 330, 53-62. $930 \quad$ https://doi.org/10.1016/j.jhydrol.2006.04.036

931 Witthuser, K., Reichert, B., Hotzl, H., 2003. Contaminant Transport in Fractured Chalk: Laboratory and 932 Field Experiments. Ground Water 41, 806-815. https://doi.org/10.1111/j.1745-6584.2003.tb02421.x 933

934 
935

936

937

938

939

940

941
- Comprehensive set of characterization methods applied in limestone aquifer units

- Lower hydraulic conductivities in crushed than in fractured limestone detected

- Major horizontal transport and low vertical connectivity revealed by tracer tests

- Matrix diffusion characterized by tracers with different diffusion coefficients

- Hydraulic tests yielded similar properties for bryozoan and calcarenitic limestone 